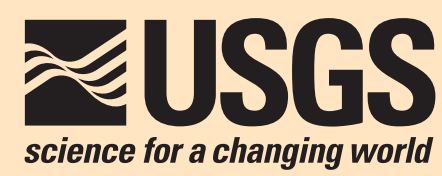

Global Mineral Resource Assessment

\title{
Sandstone Copper Assessment of the Teniz Basin, Kazakhstan
}

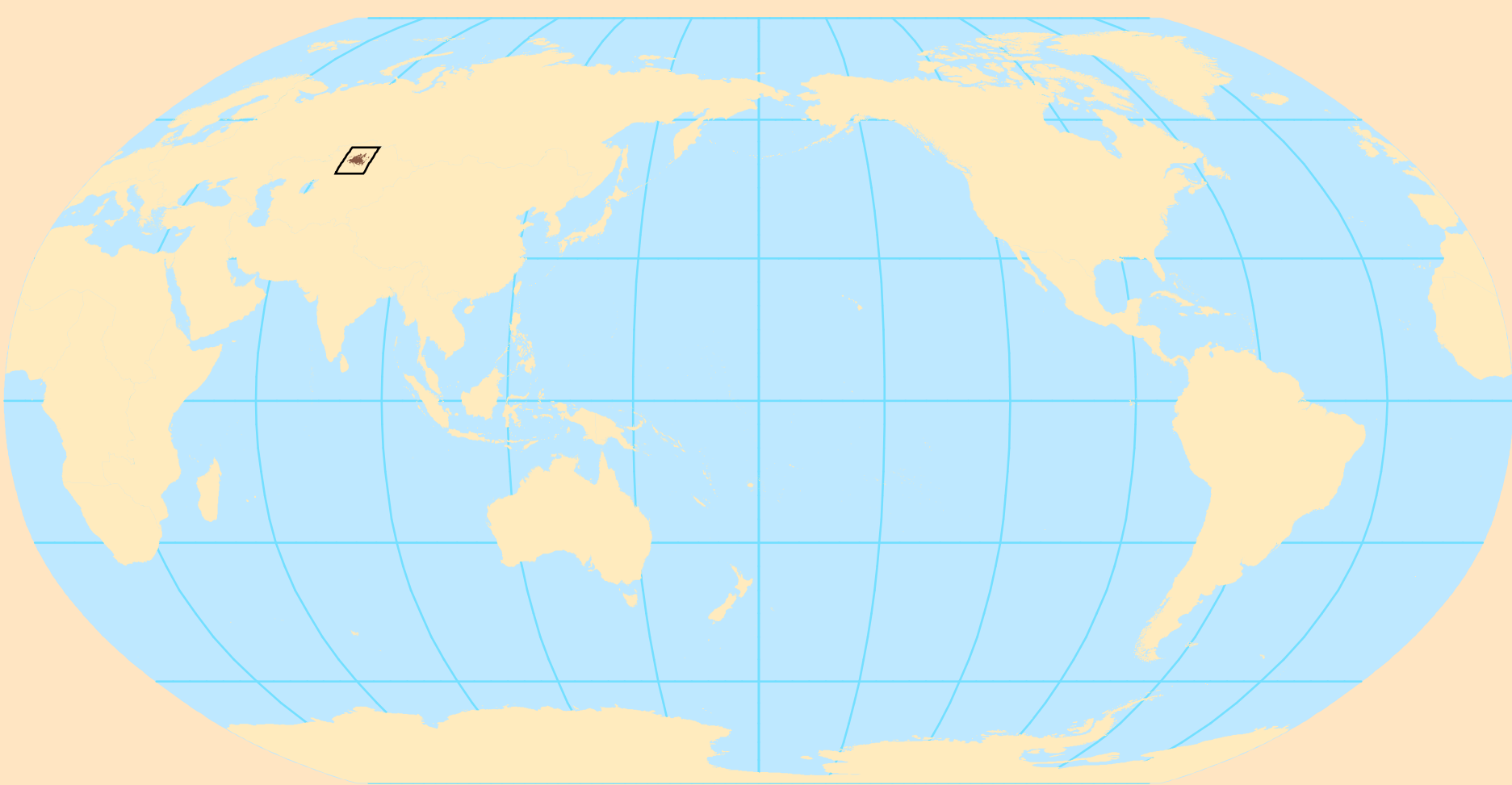

Scientific Investigations Report 2010-5090-R 
This page intentionally left blank. 


\section{Global Mineral Resource Assessment}

Michael L. Zientek, Jane M. Hammarstrom, and Kathleen M. Johnson, editors

\section{Sandstone Copper Assessment of the Teniz Basin, Kazakhstan}

By Pamela M. Cossette, Arthur A. Bookstrom, Timothy S. Hayes, Gilpin R.

Robinson, Jr., John C. Wallis, and Michael L. Zientek

Scientific Investigations Report 2010-5090-R 


\title{
U.S. Department of the Interior SALLY JEWELL, Secretary
}

\section{U.S. Geological Survey Suzette M. Kimball, Acting Director}

\author{
U.S. Geological Survey, Reston, Virginia: 2014
}

For more information on the USGS - the Federal source for science about the Earth, its natural and living resources, natural hazards, and the environment, visit http://www.usgs.gov or call 1-888-ASK-USGS.

For an overview of USGS information products, including maps, imagery, and publications, visit http://www.usgs.gov/pubprod

To order this and other USGS information products, visit http://store.usgs.gov

Any use of trade, firm, or product names is for descriptive purposes only and does not imply endorsement by the U.S. Government.

Although this information product, for the most part, is in the public domain, it also may contain copyrighted materials as noted in the text. Permission to reproduce copyrighted items must be secured from the copyright owner.

Suggested citation:

Cossette, P.M., Bookstrom, A.A., Hayes, T.S., Robinson, G.R., Jr., Wallis, J.C., and Zientek, M.L., 2014,

Sandstone copper assessment of the Teniz Basin, Kazakhstan: U.S. Geological Survey Scientific Investigations Report 2010-5090-R, 42 p., and spatial data, http://dx.doi.org/10.3133/sir20105090R.

ISSN 2328-0328 (online) 


\section{Contents}

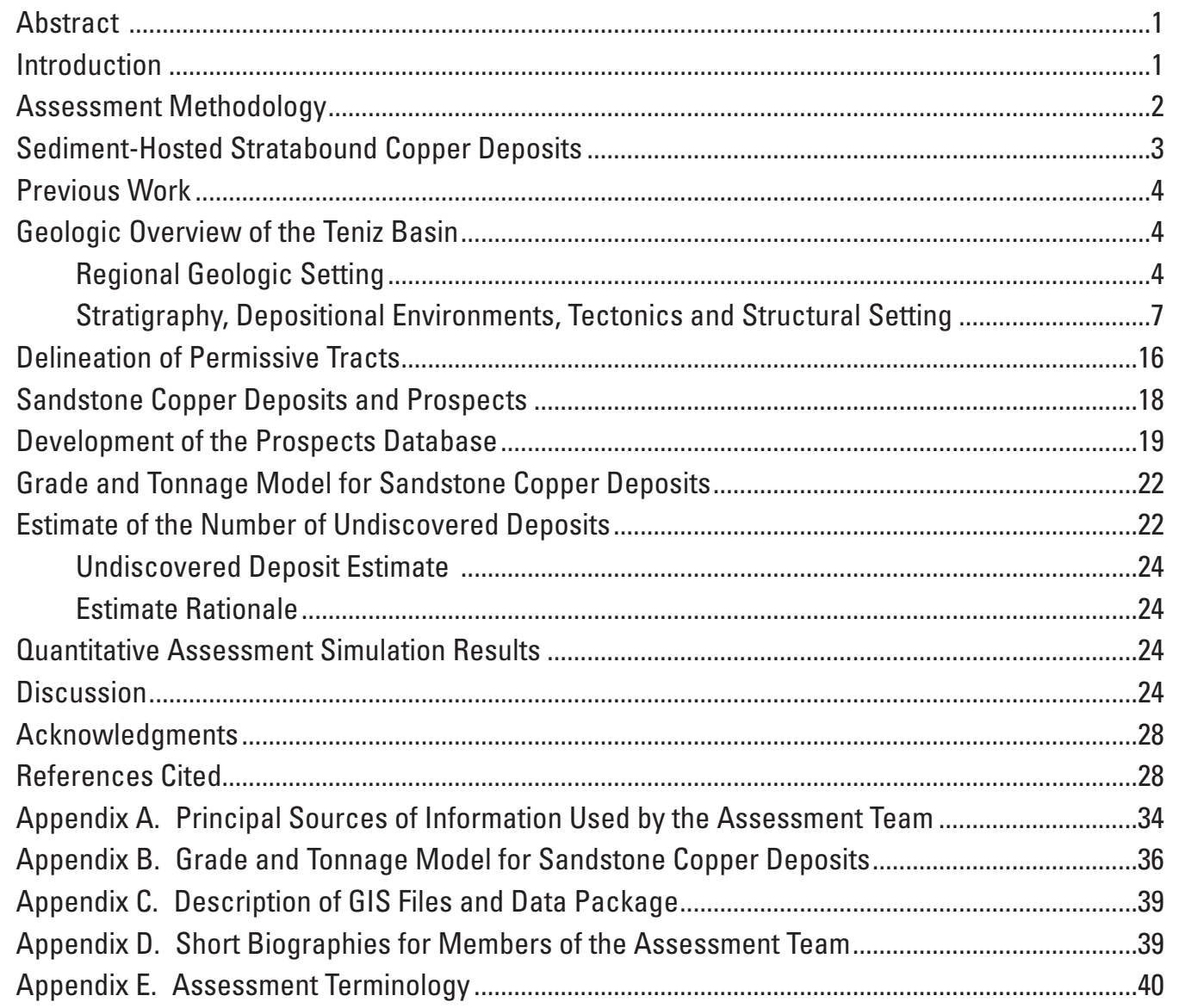




\section{Figures}

1. Map showing the regional geologic setting of the Teniz Basin, Kazakhstan ....................5

2. Generalized stratigraphic column, western Teniz Basin, Kazakhstan...............................6

3. Correlation chart for the Chu-Sarysu Basin, the western Teniz Basin, and the Zharysbay area, eastern Teniz Basin, Kazakhstan .

4. Map showing contours of the T1 reflecting horizon, traces of fold axes, and sediment-hosted stratabound copper prospects in the Teniz Basin, Kazakhstan .........14

5. Interpreted seismic section from the Teniz Basin, Kazakhstan

6. Geologic map showing the extent of the Teniz Basin, Kazakhstan and the bedrock distribution of Carboniferous and Permian rock units.

7. Map showing location of 1:200,000-scale geological and mineral resource map sheets used in this study

8. Map showing location of permissive tract 142ssCu8050 (TZ-1) and known prospects, Teniz Basin, Kazakhstan

9. Cumulative frequency plots of grade and tonnage for 70 sandstone deposits................23

10. Map showing tract 142 ssCu8050 (TZ-1) and prospects in relation to prospective areas

11. Graph comparing individual and consensus estimates of the number of undiscovered sandstone copper deposits in tract 142ssCu8050 (TZ-1), Teniz Basin, Kazakhstan

12. Cumulative frequency plot showing the results of a Monte Carlo computer simulation of undiscovered sandstone copper resources in tract 142 ssCu8050 (TZ-1), Teniz Basin, Kazakhstan.

13. Histogram showing the results of a Monte Carlo computer simulation of undiscovered sandstone copper resources in tract 142ssCu8050 (TZ-1), Teniz Basin, Kazakhstan

\section{Tables}

1. Translations of Russian map unit descriptions from 1:200,000-scale geologic maps from the western part of the Teniz Basin, Kazakhstan

2. Categorization of sediment-hosted stratabound copper occurrence in data sources used to compile a prospects database for this assessment

3. Significant Upper Carboniferous and Lower Permian sandstone copper prospects, Teniz Basin, Kazakhstan

4. Estimates by individual assessment team members of the number of undiscovered sandstone copper deposits in tract 142ssCu8050 (TZ-1), Teniz Basin,

Kazakhstan.

5. Consensus estimate of the number of undiscovered sandstone copper deposits in tract 142ssCu8050 (TZ-1), Teniz Basin, Kazakhstan

6. Results of Monte Carlo simulations of undiscovered resources in sandstone copper deposits in tract 142ssCu8050 (TZ-1), Teniz Basin, Kazakhstan ...........................28

A1. List of principal sources used to compile database

B1. Deposit data used to develop grade and tonnage model for sandstone copper deposits

B2. Summary statistics for sandstone copper deposits. 


\section{Conversion Factors, Abbreviations and Acronymns, and Chemical Symbols}

\section{Conversion Factors}

\begin{tabular}{lcl}
\multicolumn{1}{c}{ Multiply } & & \\
\hline & By & \multicolumn{1}{c}{ To obtain } \\
\hline foot (ft) & Length & \\
mile (mi) & 0.3048 & meter (m) \\
yard (yd) & 1.609 & kilometer (km) \\
& 0.9144 & meter (m) \\
\hline acre & Area & \\
acre & 0.4047 & hectare (ha) \\
square mile (mi $\left.{ }^{2}\right)$ & 0.004047 & square kilometer $\left(\mathrm{km}^{2}\right)$ \\
square mile (mi $\left.{ }^{2}\right)$ & 259.0 & hectare (ha) \\
\hline & 2.590 & square kilometer $\left(\mathrm{km}^{2}\right)$ \\
\hline ounce, troy (troy oz) & Mass & \\
ounce, troy (troy oz) & 31.103 & gram (g) \\
ton, short (2,000 lb) & 0.0000311 & megagram $(\mathrm{Mg})$ \\
\hline
\end{tabular}

SI to Inch/Pound

\begin{tabular}{|c|c|c|}
\hline Multiply & By & To obtain \\
\hline \multicolumn{3}{|c|}{ Length } \\
\hline meter (m) & 3.281 & foot (ft) \\
\hline kilometer (km) & 0.6214 & mile (mi) \\
\hline meter (m) & 1.094 & yard (yd) \\
\hline \multicolumn{3}{|c|}{ Area } \\
\hline hectare (ha) & 2.471 & acre \\
\hline square kilometer $\left(\mathrm{km}^{2}\right)$ & 247.1 & acre \\
\hline hectare (ha) & 0.003861 & square mile $\left(\mathrm{mi}^{2}\right)$ \\
\hline square kilometer (km²) & 0.3861 & square mile $\left(\mathrm{mi}^{2}\right)$ \\
\hline \multicolumn{3}{|c|}{ Mass } \\
\hline gram (g) & 0.03215 & ounce, troy (troy oz) \\
\hline megagram (Mg) & 32,151 & ounce, troy (troy oz) \\
\hline megagram (Mg) & 1.102 & ton, short (2,000 lb) \\
\hline megagram (Mg) & 0.9842 & ton, long $(2,240$ lb) \\
\hline \multicolumn{3}{|c|}{ Other conversions used in this report } \\
\hline metric ton (t) & 1 & megagram (Mg) \\
\hline troy ounce per short ton & 34.2857 & gram per metric ton $(\mathrm{g} / \mathrm{t})$ \\
\hline percent & 10,000 & $\begin{array}{l}\text { parts per million }(\mathrm{ppm}) \text { or grams } \\
\text { per metric ton }(\mathrm{g} / \mathrm{t})\end{array}$ \\
\hline percent metal & $\begin{array}{l}0.01 \times \text { metal grade, percent } \times \text { ore } \\
\text { tonnage, metric tons }\end{array}$ & metric tons of metal \\
\hline
\end{tabular}




\section{Acronyms and Abbreviations Used}

\begin{tabular}{ll}
\hline${ }^{\circ} \mathbf{C}$ & degree Celsius \\
$\mathbf{C O M E C O N}$ & $\begin{array}{l}\text { Council for Mutual Economic Assistance, an economic organization } \\
\text { (from 1949 to 1991) of Eastern Bloc countries, under the leadership of }\end{array}$ \\
& the Soviet Union \\
$\mathbf{g / t}$ & grams per metric ton \\
$\mathbf{G I S}$ & geographic information system \\
$\mathbf{k}$ & thousand \\
$\mathbf{k m}$ & kilometer \\
$\mathbf{k m} \mathbf{2}^{\mathbf{2}}$ & square kilometer \\
$\mathbf{k t}$ & thousand metric tons \\
$\mathbf{m}$ & meter \\
$\mathbf{M a}$ & millions of years before the present \\
$\mathbf{M o z}$ & million ounces \\
$\mathbf{M t}$ & million metric tons \\
$\mathbf{P G E}$ & platinum-group element(s) \\
$\mathbf{p p m}$ & parts per million \\
$\mathbf{S S I B}$ & small-scale digital international boundaries \\
$\mathbf{t}$ & metric ton (tonne) or megagram (Mg) \\
$\mathbf{U S G S}$ & United States Geological Survey \\
\hline
\end{tabular}

\section{Chemical Symbols Used}

\begin{tabular}{ll}
\hline $\mathbf{A g}$ & silver \\
Cu & copper \\
\hline
\end{tabular}




\title{
Sandstone Copper Assessment of the Teniz Basin, Kazakhstan
}

\author{
By Pamela M. Cossette' ${ }^{1}$ Arthur A. Bookstrom ${ }^{1}$, Timothy S. Hayes², Gilpin R. Robinson, Jr. ${ }^{3}$, John C. Wallis', \\ and Michael L. Zientek ${ }^{1}$
}

\section{Abstract}

The U.S. Geological Survey (USGS) conducts national and global resource assessments (mineral, energy, water, and biological) to provide data and scientific analyses to support decision making. Three-part mineral resource assessments result in informed, unbiased, quantitative, and probabilistic estimates of undiscovered mineral resources and deposits. In particular, mineral assessment results inform decisions concerning land-use and mineral-resource development. A probabilistic mineral resource assessment of the sandstone subtype of sediment-hosted stratabound copper deposits in the Teniz Basin, Kazakhstan, was undertaken by the USGS.

The Teniz Basin is located in Akmola Oblast, central and western Kazakhstan. With an areal extent of almost $78,000 \mathrm{~km}^{2}$, the basin contains many sediment-hosted stratabound copper prospects, none of which are well described, and the majority of which may belong to the sandstone subtype of sediment-hosted copper deposits. There are no known locations within the Teniz Basin currently mined for copper. Within the basin, however, map units permissive for the sandstone subtype of sedimenthosted stratabound copper deposits include (from oldest to youngest): the Middle Carboniferous Kiery Suite; the Middle to Upper Carboniferous Vladimirov Suite (a stratigraphic equivalent of the Dzhezkazgan Suite, Chu-Sarysu Basin); and the Upper Carboniferous or lowest Permian Kayraktin Suite. The multicolored sedimentary rocks of the Vladimirov Suite, in which 14 potentially ore-bearing horizons of gray beds have been recorded, have the greatest potential for undiscovered, sandstone subtype, sediment-hosted stratabound copper deposits.

A quantitative mineral resource assessment has been completed that (1) delineates one $49,714 \mathrm{~km}^{2}$ tract permissive for undiscovered, sandstone subtype, sediment-hosted stratabound copper deposits, and (2) provides probabilistic estimates of numbers of undiscovered deposits and probable

\footnotetext{
${ }^{1}$ U.S. Geological Survey, Spokane, Washington, United States.

${ }^{2}$ U.S. Geological Survey, Tucson, Arizona, United States.

${ }^{3}$ U.S. Geological Survey, Reston, Virginia, United States.
}

amounts of copper resource contained in those deposits. The permissive tract delineated in this assessment encompasses no previously known sandstone subtype, sediment-hosted stratabound copper deposits. However, this assessment estimates (with 30 percent probability) that a mean of nine undiscovered sandstone subtype copper deposits may be present in the Teniz Basin and could contain a mean total of 8.9 million metric tons of copper and 7,500 metric tons of silver.

\section{Introduction}

In response to the growing demand for information on the global mineral-resource base, the U.S. Geological Survey (USGS) conducted a global assessment of undiscovered copper resources (Briskey and others, 2001; Zientek and Hammarstrom, 2008). This assessment focuses on the two deposit types that host most of the world's known copper-porphyry copper deposits and sediment-hosted stratabound copper deposits (Singer, 1995). As part of the global assessment, this study assesses undiscovered resources associated with the sandstone subtype of sediment-hosted stratabound copper deposits in the middle to upper Paleozoic Teniz Basin, Kazakhstan.

Global resource assessments address two questions: (1) where are undiscovered resources likely to exist, and (2) how much undiscovered resource may be present? Mineral potential maps show where undiscovered resources may be present and the amount of undiscovered resource is reported as a probability distribution of in-place, undiscovered metal. This report summarizes the regional geologic setting and stratigraphy of the Teniz Basin and the distribution of sediment-hosted stratabound copper prospects. One tract, permissive for sandstone subtype, sediment-hosted copper, is delineated based upon the results of (1) a comprehensive literature review; (2) GIS data processing, evaluation, and analysis; (3) a regional geologic data synthesis; and (4) expert estimation of the probability of undiscovered, sandstone subtype, sediment-hosted stratabound copper deposits in the basin. Appendix A summarizes the principal information sources used in this assessment. Appendix B provides grade 
and tonnage model information used in resource estimation. Appendix C describes geographic information system (GIS) data files for the permissive tract and prospects. Appendix D provides biographical information about assessment team members. Finally, a glossary of terminology used in mineral assessments is provided in appendix E.

Permissive tracts are based on geology, irrespective of current land-use conditions. Therefore, tracts may include lands that already have been developed for other uses, or have been withdrawn from mineral development as protected areas. The tracts are compiled to be displayed at a scale of 1:1,000,000. Even though higher resolution information may have been used in the compilations, this information is intended for use at scales no larger than 1:1,000,000.

\section{Assessment Methodology}

Geologists, engineers, and miners have long recognized that mineral deposits can be classified into groups or types on the basis of common features and associations. A mineral deposit type is associated with distinctive geologic settings that can be recognized on geologic maps, cross sections, and stratigraphic columns. In addition, each mineral deposit type has characteristic geometries, grade and tonnage distributions, and rock and mineral properties that determine the potential value of the deposit, sampling density required to delimit the resource, and ore mining and processing methods. These deposit-type parameters collectively exert specific physical effects on the environment, whether through natural weathering processes or mining and can influence the decision-making process regarding feasibility. Mineral resource assessment methodology uses mineral deposit models to discriminate areas with mineral potential from those that are barren, and places value on the resources that may be present.

This study uses the three-part assessment form described by Singer (1993) and Singer and Menzie (2010) to estimate location and probable amounts of undiscovered resources for the sandstone subtype of sediment-hosted stratabound copper. Undiscovered resources include mineralized material whose location, grade, quality, and quantity are unknown or incompletely characterized, either in partially-characterized sites or completely unknown mineral deposits.

Location.-Using the geologic environment summarized in descriptive deposit models, areas in which geology permits the existence of a specific deposit type are selected and delineated. The delineated area, or permissive tract, represents the surface projection of a volume of the Earth's crust corresponding to a geologic environment described by the deposit model; consequently, assessment depth selection is essential to tract definition. In this study, we assess undiscovered resources to a depth of $2 \mathrm{~km}$ (kilometers) below the Earth's surface.
Probable amounts. - Assessments are based on analogy: undiscovered resources of a particular type are assumed to be comparable to those that have been discovered elsewhere in the world. The amount of undiscovered resource is derived from (1) grade and tonnage models for known deposits of the same type, in geologically similar settings, and (2) an estimate of a fixed, but unknown, number of undiscovered deposits that exist in delineated tracts. Grade and tonnage models are based on average grade and frequency distributions of tonnage in well-explored deposits. The distribution of undiscovered deposits is estimated by expert panels at several probability percentiles. From these estimates, a probability distribution for undiscovered deposits is obtained using an algorithm provided by Root and others (1992). Monte Carlo simulation is then used to combine grade and tonnage models with the probability distribution of undiscovered deposits to obtain probability distributions for undiscovered metals in each tract (Root and others, 1996; Duval, 2012; Bawiec and Spanski, 2012). Simulation results are then presented in summary tables and graphs. This quantitative mineral resource assessment can subsequently be evaluated by applying economic filters and cash flow models for economic and policy analysis: the results can be applied to mineral supply, economic, environmental, and land-use planning. Economic evaluations, however, are not part of this report.

Mineral inventories are the formal quantification of naturally occurring mineral materials, estimated by a variety of empirically or theoretically based procedures (Sinclair and Blackwell, 2002). Mineral resources are defined as concentrations or occurrences of material of economic interest in or on the Earth's crust in such form, quality, and quantity that there are reasonable prospects for eventual economic extraction. The location, quantity, grade, continuity, and other geological characteristics of a mineral resource are known, estimated, or interpreted from specific geological evidence, sampling, and knowledge (Committee for Mineral Reserves International Reporting Standards, 2006). The term "mineral reserve" is restricted to the economically mineable part of a mineral resource.

In this report, we restrict usage of the word "deposit" to those sites that (1) formed by the same genetic process (same deposit type), (2) may have economic potential, (3) have a mineral inventory defined by a sampling density appropriate for the deposit type, and (4) are well explored (most mineralized rock at the site is included in a mineral inventory). Because no copper-mineralized sites within the study area satisfy all of these requirements, "deposits" are considered absent in the Teniz Basin. Consequently, sites that do not have have a published mineral inventory or are incompletely explored are referred to as "prospects" in this report. "Significant prospects" are those sites that are consistently documented in various data sources and may be referred to as "small deposits," even though tonnage and grade is not reported. 


\section{Sediment-Hosted Stratabound Copper Deposits}

Sediment-hosted stratabound copper mineralization consists of fine-grained copper sulfide and copper-iron-sulfide minerals that occur as stratabound to stratiform disseminations in siliciclastic or dolomitic sedimentary rocks (Zientek, Hayes, and Hammarstrom, 2013). Ore minerals occur as cements and replacements, and less commonly as veinlets. Sulfide mineral concentrations conform closely, but not exactly, with stratification of host rocks. Ore zones typically comprise chalcocite and bornite. Deposits are commonly characterized by lateral zoning of ore minerals along and across bedding, from pyrite to chalcopyrite to bornite to chalcocite to hematite. Deposits are hosted in black, gray, green, or white (chemically reduced) sedimentary strata within or above a thick section of red (oxidized) beds.

Two genetic concepts on the origin of sediment-hosted stratabound copper deposits have been discussed in the scientific literature: (1) syngenesis, in which ore minerals developed simultaneously with sediment deposition, and (2) diagenesis, in which copper mineralization occurred after sediment deposition, from processes occurring at relatively low temperatures and pressures during compaction and lithification. The syngenetic theory was first proposed in the 18th century (Lehmann, 1756) followed by papers from Scheiderhölm (1932) and Garlick (1961) that led to model acceptance in the 1960s; papers promoting this concept were published into the late 20th century. The diagenetic model arose out of work published by White and Wright (1954), Bartholomé (1964), Rentzsch (1965), and Rydzewski (1969). For decades, the model debate went unresolved because there were no basic scientific data on age, formation temperatures, or ore fluid compositions for sediment-hosted stratabound copper deposits (Jowett, 1991). The diagenetic model of ore formation is now widely accepted and forms the basis for assessment work in this report. Jowett (1991) and Hitzman and others (2005) summarize the evolution of ideas on genesis of sediment-hosted stratabound copper deposits.

The regional and stratigraphic association of stratabound copper ores with evaporites and red bed deposits, described by Davidson (1965), Rose (1976), and Kirkham (1989), provides evidence for the composition of ore-forming fluid and factors controlling deposit distribution. Sediment-hosted stratabound copper mineralizing processes are limited to sedimentary or metasedimentary formations younger than 2,300 Ma, when free oxygen first appeared in Earth's atmosphere (Bekker and others, 2004; Canfield, 2005; Hitzman and others, 2010) and the earliest red beds formed (Chandler, 1988; Bekker and others, 2004). Red beds can form in a variety of environments, but sediment-hosted stratabound copper deposits are most commonly associated with those deposited in arid climates. These include sediments that were originally deposited in aeolian dunes, sabkhas, playas, and sand sheets, with lesser associations in host rocks deposited by alluvial fans, and ephemeral rivers. Intracontinental rift basins that formed within 20-30 degrees of the equator are ideal settings for sediment-hosted stratabound copper deposits (Kirkham, 1989), but transtensional basins and intermontane basins also contain sediment-hosted stratabound copper deposits.

Field and laboratory evidence indicates that sedimenthosted stratabound copper mineral deposits formed from late diagenetic fluids generated during the compaction and lithification of sedimentary basins containing successions of red beds (Hitzman and others, 2005; 2010). On the basis of ore and gangue mineral zoning and alteration, mineral paragenesis, fluid inclusion studies, and stable isotope geochemistry, metal-bearing fluids are relatively lowtemperature $\left(75-220^{\circ} \mathrm{C}\right)$, hematite-stable (oxidized), sulfateand chloride-rich, subsurface sedimentary brines.

Host lithology, and the nature of organic material in the rock, are used to distinguish three subtypes of sedimenthosted stratabound copper deposits: (1) reduced facies, (2) sandstone copper, and (3) red bed (Cox and others, 2003; Zientek, Hayes, and Hammarstrom, 2013). Host rocks for reduced-facies subtype sediment-hosted stratabound copper deposits include laterally-extensive black shale, dark-gray to black siltstone, dark-gray dolosiltstone, gray shale, or locally green shale or siltstone-all of which contain solid organic material. Host rocks for sandstone copper are typically well-sorted, siliciclastic sandstones from a variety of deltaic topset environments. Petroleum-bearing fluid inclusions and dead oil that coat detrital grains, stain authigenic minerals, and locally form cements, indicate that the mineralized strata may have hosted petroleum accumulations. For many sandstone copper deposits, these accumulations may have been sour gas (Zientek, Hayes, and Hammarstrom, 2013). Host rocks for red bed subtype deposits are fluvial sandstone, commonly conglomeratic, and contain carbonized vascular plant fragments. The ability to distinguish between subtypes is important for resource assessment studies because red bed subtype deposits are usually too small to be mined economically, whereas sandstone subtype deposits are important sources of copper ${ }^{4}$, supplying 5 percent of the world's copper (Zientek, Hayes, and Hammarstrom, 2013). The primary cause of base-metal sulfide precipitation for reduced-facies or red bed deposits is the reduction of sulfate in brine by organic material; in sandstone copper deposits, it is direct sulfide precipitation by hydrogen sulfide (Zientek, Hayes, and Hammarstrom, 2013).

\footnotetext{
${ }^{4}$ Taylor and others (2013) state that global production of copper is largely derived from porphyry and sediment-hosted copper deposits (57 and 23 percent, respectively). In 2011, global copper production was almost $313 \mathrm{Mt}$ of which almost $71 \mathrm{Mt}$ was derived from Sandstone copper and Sandstone copper—-Roan arenite subtypes (Taylor and others, 2013).
} 


\section{Previous Work}

Detailed geologic mapping and mineral exploration studies were conducted in Kazakhstan, after the Second World War, by the Dzhezkazgan Exploratory-Geologic Expedition (Popov, 1962). Areas with mineral-resource potential were mapped at scales ranging from 1:50,000 to 1:10,000. Maps at a scale of 1:200,000 were later compiled to illustrate the regional geology and to provide basis for a prognostic assessment of mineral potential. In the Teniz Basin area, 1:200,000-scale geologic and minerals maps published between 1957 and 1970 are based on field work conducted between 1951 and 1962. The minerals maps show stream sediment survey results and location and relative size of mineral occurrences. A few English-language publications that specifically describe sediment-hosted copper mineralization in this area were published between 1960 and 1974 (Popov, 1962; Bogdanov and Feoktistov, 1972; Seyfullin and others, 1974). Those publications refer to an extensive Russian scientific literature that was not available for this study. We did, however, have access to an English-translated overview of stratabound copper deposits of the USSR (Bogdanov and others, 1973).

References to resource potential of the Teniz Basin can be found in Bogdanov and Feoktistov (1972), Syusyura and others (2010), and Information and Analysis Center of Geology and Mineral Resources of the Republic of Kazakhstan, (2008). Bogdanov and Feoktistov (1972) suggest that the potential for undiscovered copper in the southern part of the basin is quite high and show a mineral potential map with areas that have factors favorable for mineralization (their figure 6).

Syusyura and others (2010) published a data compilation useful for understanding copper potential in the Teniz Basin. The data include a digital geologic map at a scale of $1: 1,500,000$, a database of mineral localities, results from seismic surveys, and a copper forecast map. The copper forecast map in Syusyura and others (2010) shows prognostic areas categorized according to potential, priority, and need for additional study. The Teniz Basin is one of six areas that have prognostic resources associated with cupriferous sandstone in Kazakhstan (Information and Analysis Center of Geology and Mineral Resources of the Republic of Kazakhstan, 2008).

We suspect that most copper exploration activities were conducted in the 1950s because the distribution of mineral locations shown on the 1:1,000,000-scale minerals map (Marochkin and others, 1994) is virtually the same as that shown on the 1:200,000-scale (1950s) maps. Internet searches for recent exploration activity within the Teniz Basin failed to identify any commercial interest or activity. Google Earth imagery shows no evidence for construction of new roads, drill pads, or trenches at mineral localities since that time. Evenly-spaced exploration trenches were seen in images near Kenen and Kiyminskoe, but the ground disturbance is not recent.
The Teniz Basin has also been explored for oil and gas. Seismic data were collected in two periods of exploration: 1952-1954 and 1975-1982. In all, 865 line km of common depth point and 7,000 line $\mathrm{km}$ of analog reflection seismic data were collected in the basin (Oil \& Gas Journal, 1992; Syusyura and others, 2010). In the late 1970s and early 1980s, 20 holes with depths ranging from 200 to 3,000 m were drilled to test stratigraphy (Oil \& Gas Journal, 1995; Syusyura and others, 2010). In one hole, methane flowed for about 30 hours from a Middle ${ }^{5}$ Carboniferous interval penetrated at $812 \mathrm{~m}$ (Oil \& Gas Journal, 1995).

\section{Geologic Overview of the Teniz Basin}

\section{Regional Geologic Setting}

The Paleozoic Teniz and Chu-Sarysu Basins owe their origin to the interaction of three continental blocks-Siberia, Tarim-North China, and Kazakhstan-during development of the Altaid Orogen (Wilhem and others, 2012; Blackbourn and Thomson, 2010). The basins formed along the western margin of the Paleozoic Kazakhstan Continent described by Wilhelm and others, (2012) (fig. 1). Pre-Silurian amalgamation of the Kazakhstan Continent in eastern Gondwana resulted from collision and accretion of several microcontinents and island arc-type terranes. Assembly of the continent was virtually complete by the Early Silurian, by which time an inferred suture zone, that may underlie both the Chu-Sarysu and Teniz Basins, had closed (Allen and others, 2001; Windley and others, 2007; Smirnov, 2008; Wilhelm and others, 2012). Following its amalgamation, the continent was mostly emergent during the Silurian and Early Devonian, as indicated by continental deposits and subaerial, mafic volcanic rocks that underlie the Teniz and Chu-Sarysu Basins (fig. 2).

During the Late Devonian, clastic sediment deposition ceased and was succeeded by carbonate deposition in an extensive marine platform along the western and southern margins of the Kazakhstan Continent. This passive margin formed by back-arc opening related to development of the Kazakh-Mongol continental arcs along the eastern side of the Kazakhstan Continent. Epicontinental shallow marine basins, which would become the Teniz and Chu-Sarysu Basins, developed at this time (Wilhelm and others, 2012).

\footnotetext{
${ }^{5}$ We have chosen to preserve Russian age terminology to describe Series and Epoch time intervals referenced in this report. For example, whereas USGS would use middle Carboniferous Kirey Suite, the original Russian literature and translation of that literature uses Middle Carboniferous Kirey Suite. For ease of use of references cited, we have chosen to preserve the Russian style.
} 

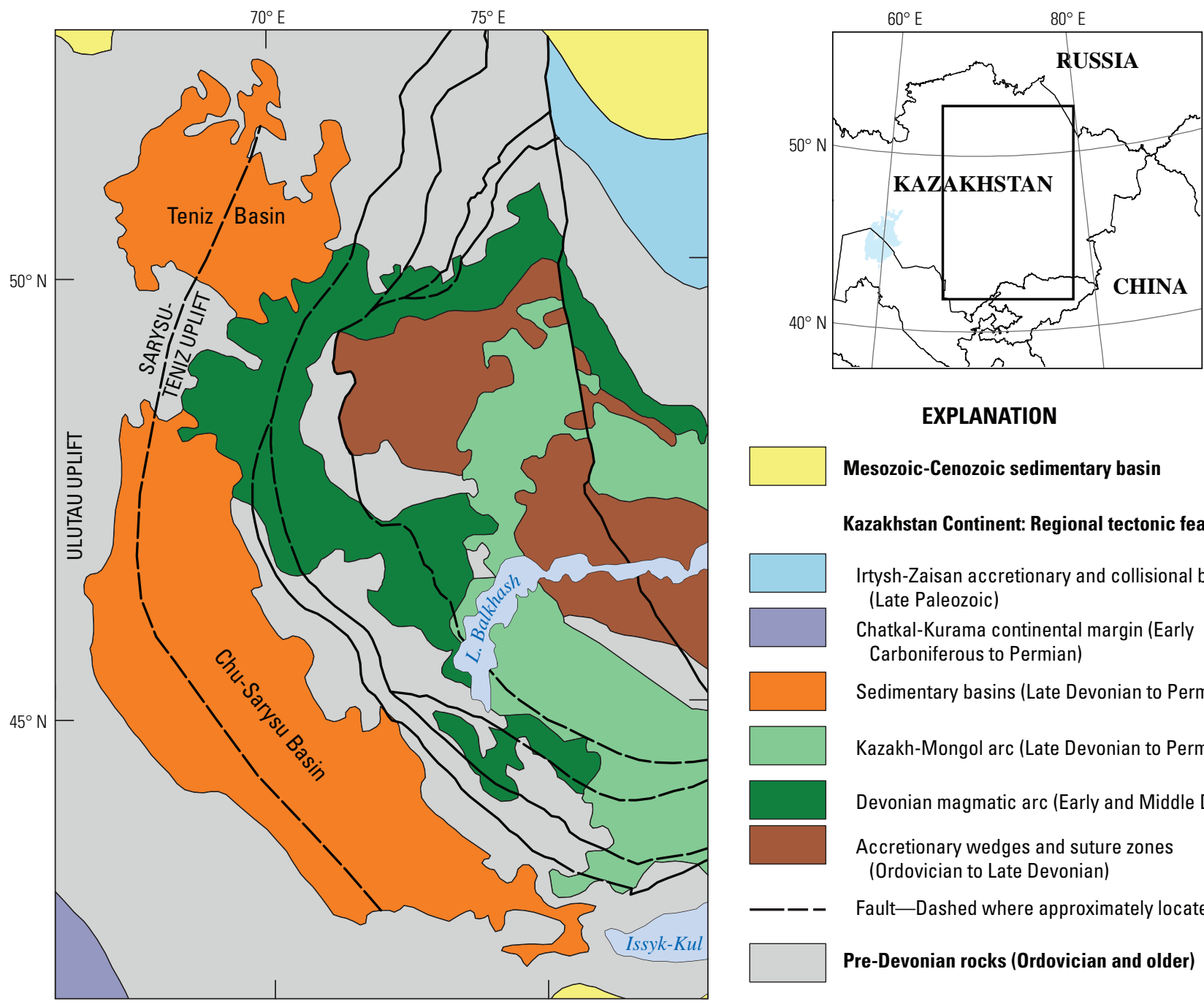

\section{EXPLANATION}

Mesozoic-Cenozoic sedimentary basin

Kazakhstan Continent: Regional tectonic features

Irtysh-Zaisan accretionary and collisional belt (Late Paleozoic)

Chatkal-Kurama continental margin (Early Carboniferous to Permian)

Sedimentary basins (Late Devonian to Permian)

Kazakh-Mongol arc (Late Devonian to Permian)

Devonian magmatic arc (Early and Middle Devonian)

Accretionary wedges and suture zones (Ordovician to Late Devonian)

Fault-Dashed where approximately located

Pre-Devonian rocks (Ordovician and older)

Political boundaries from U.S. Department of State (2009). Asia North Albers Equal Area Projection.

Central meridian, $69^{\circ} \mathrm{E}$., latitude of origin, $30^{\circ}$

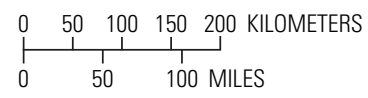

Figure 1. Map showing the regional geologic setting of the Teniz Basin, Kazakhstan (modified from Windley and others, 2007). 


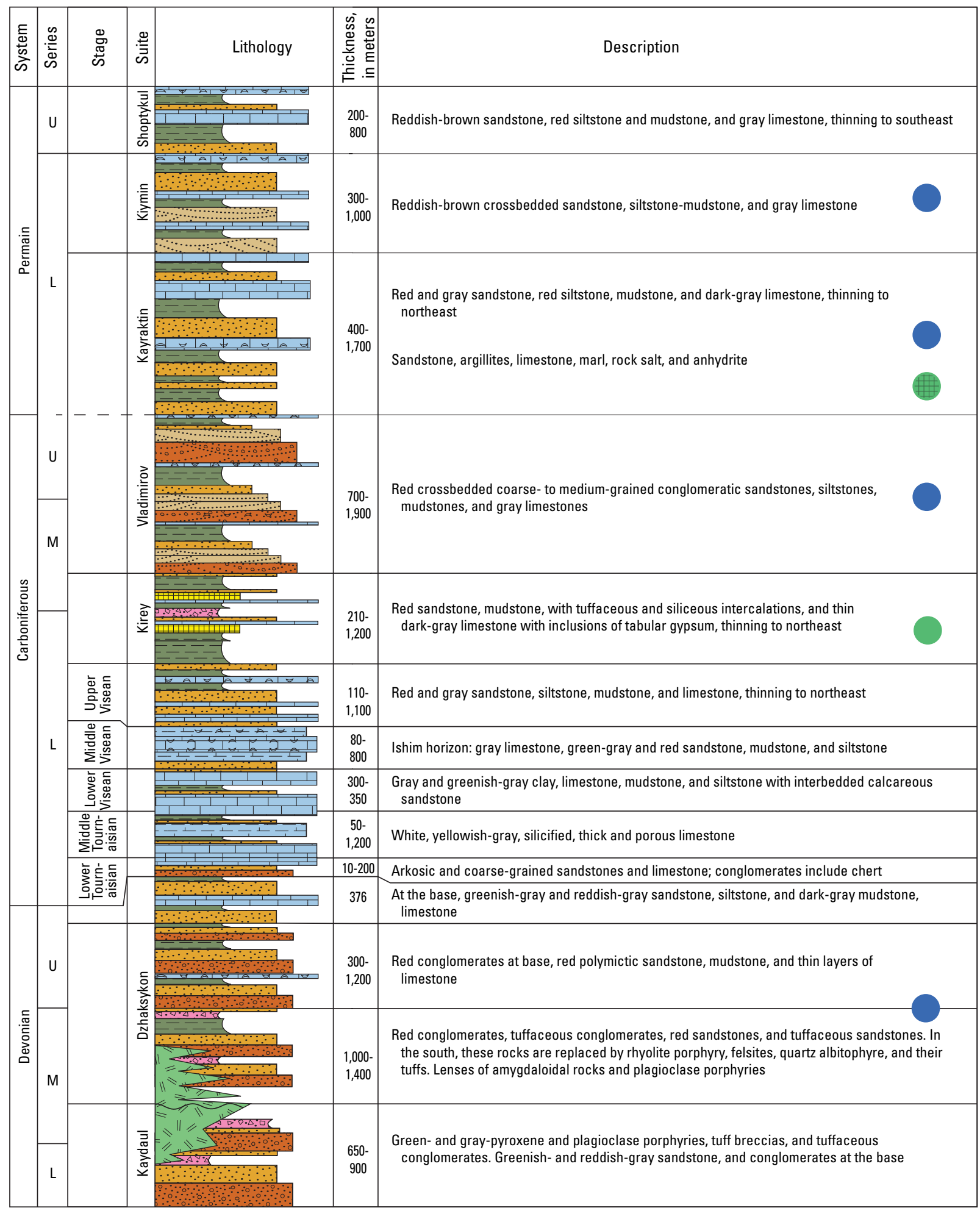

\section{EXPLANATION}

\begin{tabular}{|c|c|c|}
\hline Limestone & $\because$ Sandstone & {$\left[\begin{array}{l}1, \\
\end{array}\right.$ Tuff } \\
\hline Gypsum & $\cdots$ Crossbedded sandstone & $=\| /$ Volcanic rock \\
\hline Marl & Conglomerate & $\triangle \otimes$ Fauna \\
\hline
\end{tabular}

Figure 2. Generalized stratigraphic column, western Teniz Basin, Kazakhstan. 
Siberia, Tarim-North China, and Kazakhstan blocks continued to interact throughout the middle and late Paleozoic. Devonian marine-sedimentary and volcanic rocks, that form the base of the Teniz and Chu-Sarysu Basins, are overlain by continental deposits that record uplift resulting from closure of the Turkestan and Uralian Oceans and the continental collision between Baltica and the Kazakhstan Continent. The new plate arrangement led to oroclinal bending and largescale rotation of Kazakhstan during the Carboniferous. An east-west oriented, deep water trough that crossed the northern carbonate shelf was inverted, creating the Sarysu-Teniz uplift zone that now separates the Teniz and Chu-Sarysu Basins (Blackbourn and Thomson, 2010).

\section{Stratigraphy, Depositional Environments, Tectonics and Structural Setting}

A generalized stratigraphic column for the western half of the Teniz Basin (fig. 2) was compiled using information from 1:200,000-scale geologic maps (Mazarovich, 1958a; Minervin, 1961a; Mikhailov and Litvinovish, 1963; Babi'chev and others, 1970a). Our translations of Russian unit descriptions are given in table 1 . This column is compared to a section for the eastern edge of the Teniz Basin, Zharysbay area (Syusyura and others, 2010) and the Chu-Sarysu Basin (Box and others, 2012) in figure 3.

Stratigraphy of the Teniz Basin indicates that the depositional setting evolved from continental to marine, and back to continental. The oldest rocks (deposited over crystalline basement) in the basin, Lower and Middle Devonian volcanogenic-sedimentary deposits, are overlain by red conglomerates and sandstones of the Middle to Upper Devonian Dzhaksykon Suite that were deposited soon after amalgamation of the Kazakhstan Continent. The overlying Tournaisian to Visean (Middle Mississippian) carbonates and mudstones are marine in origin and are part of a large carbonate shelf that formed on the passive margin of the Kazakhstan Continent. These, in turn, are conformably overlain by red bed deposits beginning with the Middle Carboniferous Kirey Suite and culminating with the Upper Permian Shoptykol Suite. The sequence of rocks that constitute the copper mineralized section are bracketed by the Upper Devonian Dzhaksykon Suite and the Upper Permian Shoptykul Suite. Total thickness of the upper Paleozoic red bed units ranges from $200 \mathrm{~m}$ to 4,000 m (Bogdanov, 1960). The Middle Carboniferous continental red beds were deposited in response to marine regression and regional uplift during convergence of the Kazakhstan Continent and Baltica. The Teniz Basin subsequently evolved into an evaporative, lacustrine basin that was subject to fluctuating water levels (Bogdanov, 1960).

These generalizations are consistent with fossils described on 1:200,000-scale geologic maps (Mazorovich, 1958a; Minervin, 1961a; Mikhailov and Litvinovish, 1963; Babi'chev and others, 1970a). Marine brachiopods and gastropods are associated with the Lower Carboniferous carbonate units. Fossils of ostracods, fish, reptiles, and terrestrial plants are described from the Middle Carboniferous to Permian clastic rocks. The prominent aquatic fossil in Upper Carboniferous and Permian rocks, Darwinula sp., is commonly associated with freshwater habitats, but modern species of Darwinula sp. have a cosmopolitan distribution (Sohn, 1987) and can tolerate a wide range of salinities. Therefore the presence of $D$ arwinula sp. does not preclude the probability that the body of water that occupied the Teniz Basin remained saline throughout the close of the Carboniferous until at least the Middle Permian.

Convergence of the Kazakhstan Continent and Baltica during the late Paleozoic folded sedimentary rocks in both the Chu-Sarysu and Teniz Basins. In the Chu-Sarysu Basin, strata are deformed by two, nearly-orthogonal trends of upright folds: an east-northeasterly-trending set (F1, fig. 4) and a set with northerly trends (F2, fig. 4) and the Teniz Basin strata are similarly deformed (Allen and others, 2001; Alexeiev and others, 2009; Syusyura and others, 2010; Box and others, 2012). Isodepth maps of a reflecting horizon identified in seismic surveys suggest at least two episodes of folding occurred within the Teniz Basin. Seismic profiles show significant reflectors at the base of Tournaisian strata $\left(\mathrm{T}_{1}\right)$, lower and middle Visean strata $\left(\mathrm{T}_{2}\right)$, and the Vladimirov Suite $\left(\mathrm{T}_{3}\right)$ (fig. 5). The isodepth map for the $\mathrm{T}_{1}$ reflector (Syusyura and others, 2010) was used to map traces of fold axes (fig. 5). Geologic maps of basin margins and structure contour maps demonstrate that two fold trends affect upper Paleozoic strata throughout the basin and that wavelengths of both intersecting fold sets are approximately 10-15 km with subhorizontal fold axes and steep axial planes. Complex basin and dome fold patterns result from the interaction of northeastto east-oriented folds with near-orthogonal north-south folds. 


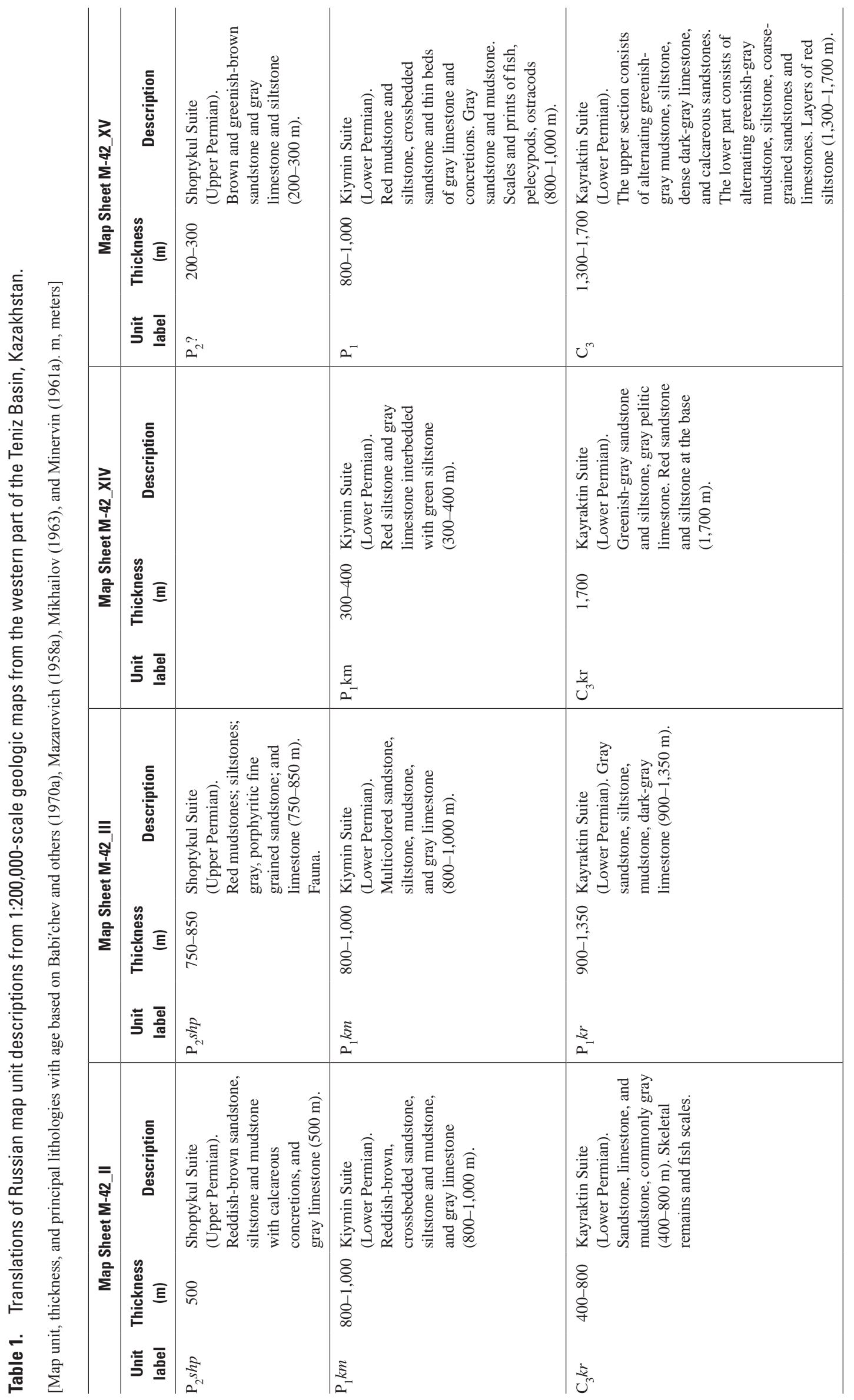




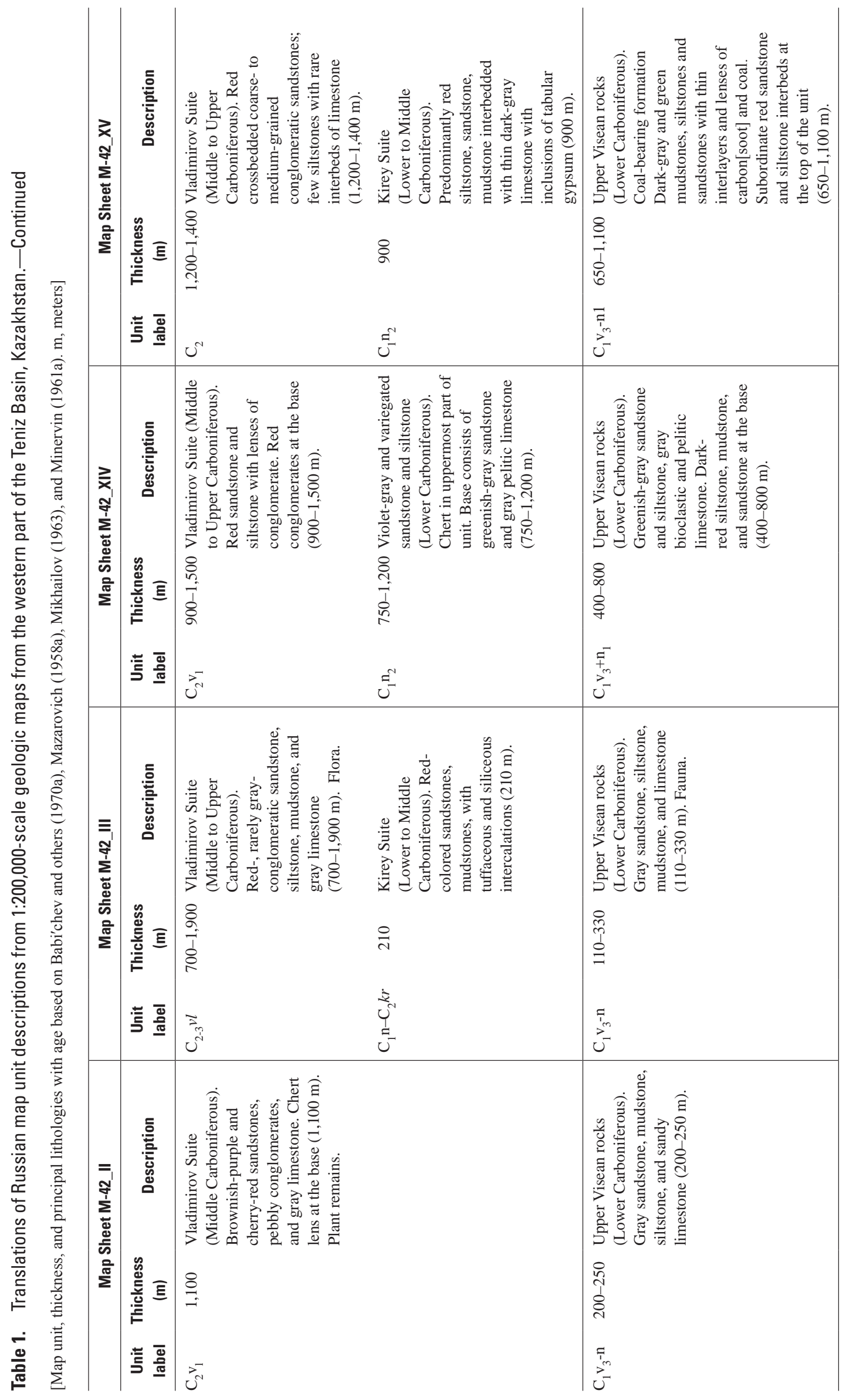




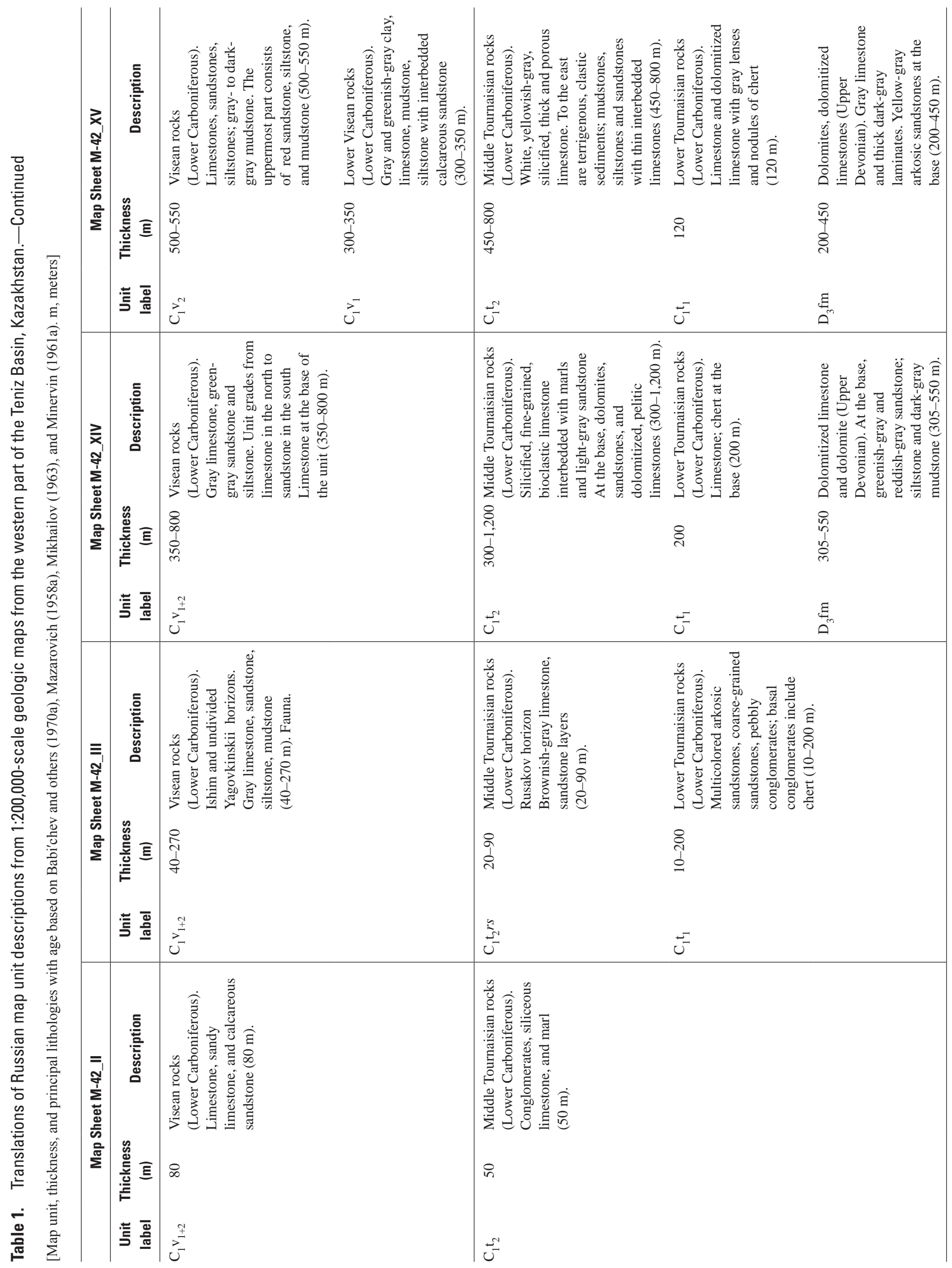




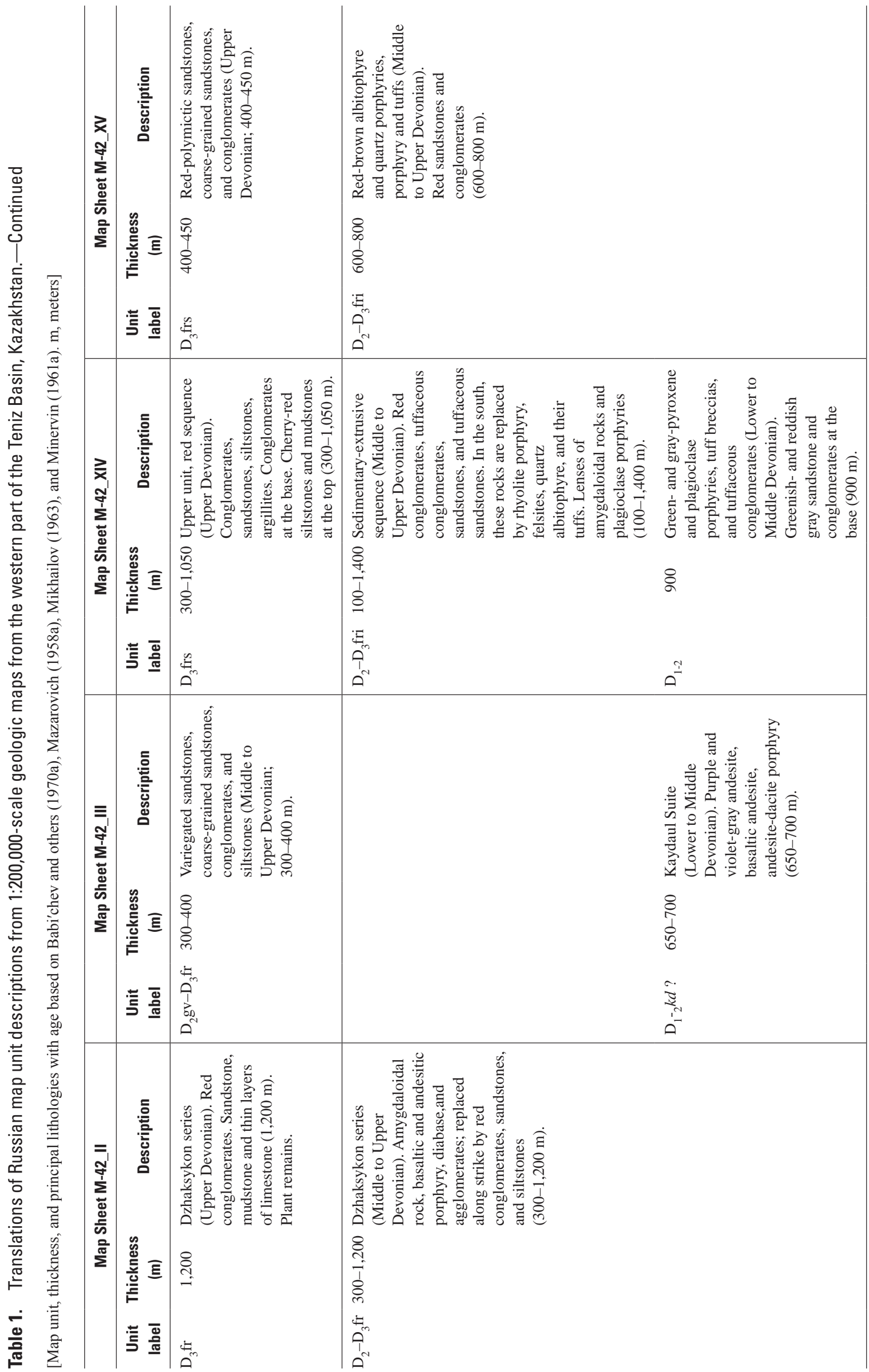




\section{Chu-Sarysu Basin}

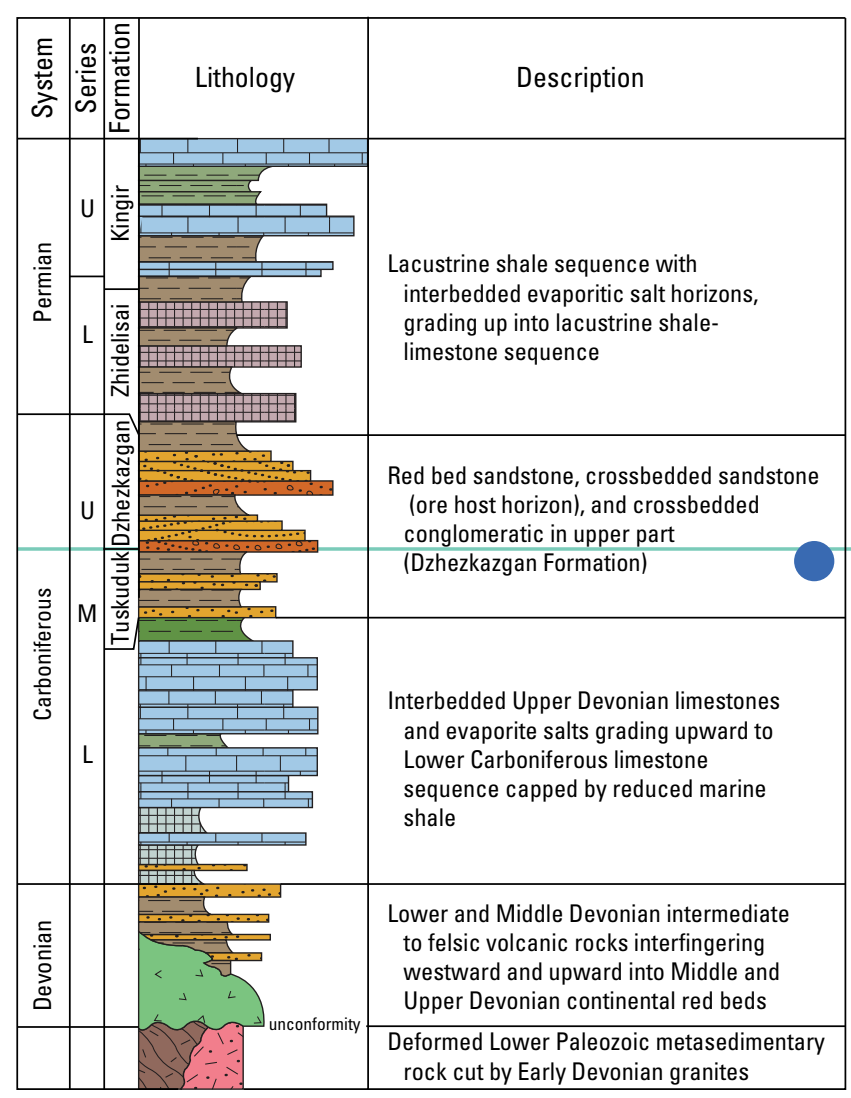

\section{EXPLANATION}

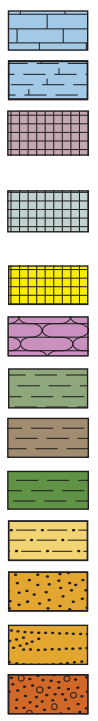

Limestone

Marl

Salt-bearing nonmarine evaporites

Salt-bearing marine evaporites

Gypsum

Chert

Siltstone/mudstone/shale

Red bed shale

Reduced marine shale

Argillite

Sandstone

Crossbedded sandstone

Conglomerate

Western Teniz Basin

\begin{tabular}{|c|c|c|c|c|c|}
\hline $\begin{array}{l}\frac{E}{d} \\
\frac{1}{\infty} \\
\text { का }\end{array}$ & $\cdot \frac{\mathscr{D}}{\Phi}$ & 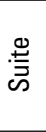 & Lithology & 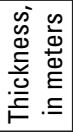 & Description \\
\hline \multirow{3}{*}{ 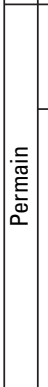 } & $U$ & $\begin{array}{l}\overline{\bar{z}} \\
\frac{\mathrm{i}}{0} \\
\end{array}$ & 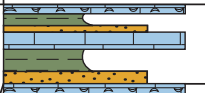 & $\begin{array}{c}200- \\
800\end{array}$ & Reddish-brown sandstone, red siltstone and mudstone, gray \\
\hline & & 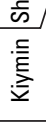 & 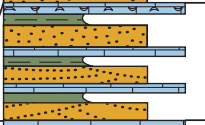 & $\begin{array}{l}300- \\
1,000\end{array}$ & Reddish-brown crossbedded sandstone, siltstone-mudston \\
\hline & $\mathrm{L}$ & 舫 & 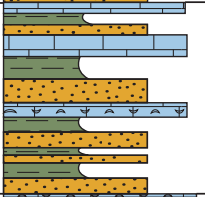 & $\begin{array}{l}400- \\
1,700\end{array}$ & $\begin{array}{l}\text { Red and gray sandstone, red siltstone, mudstone, and dark-gr } \\
\text { northeast } \\
\text { Sandstone, argillites, limestone, marl, rock salt, and anhydrite }\end{array}$ \\
\hline \multirow{7}{*}{ 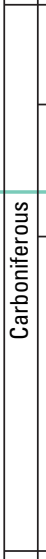 } & $\mathrm{M}$ & 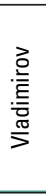 & 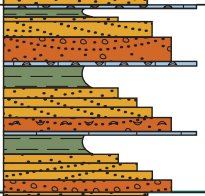 & $\begin{array}{l}700- \\
1,900\end{array}$ & $\begin{array}{l}\text { Red crossbedded coarse- to medium-grained conglomeratic } \\
\text { mudstones, and gray limestones }\end{array}$ \\
\hline & \multirow{6}{*}{$\mathrm{L}$} & 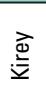 & 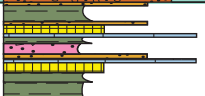 & $\begin{array}{l}210- \\
1,200\end{array}$ & $\begin{array}{l}\text { Red sandstone, mudstone, with tuffaceous and siliceous inter } \\
\text { dark-gray limestone with inclusions of tabular gypsum, thinr }\end{array}$ \\
\hline & & & 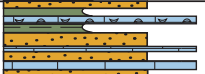 & $\begin{array}{l}110- \\
1,100\end{array}$ & Red and gray sandstone, siltstone, mudstone, and limestone, \\
\hline & & & 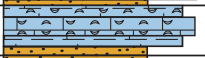 & $\begin{array}{l}80- \\
800\end{array}$ & Ishim horizon: gray limestone, green-gray and red sandstor \\
\hline & & & \begin{tabular}{|llllll} 
& & 1 & 1 & 1 \\
& & 1 & 1 & 1 \\
\end{tabular} & $\begin{array}{l}300- \\
350 \\
\end{array}$ & $\begin{array}{l}\text { Gray and greenish-gray clay, limestone, mudstone, and siltsto } \\
\text { sandstone }\end{array}$ \\
\hline & & & 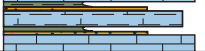 & $\begin{array}{c}50- \\
1,200\end{array}$ & White, yellowish-gray, silicified, thick and porous limestone \\
\hline & & & 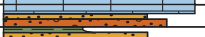 & $10-200$ & Arkosic and coarse-grained sandstones, limestone; conglom \\
\hline \multirow{4}{*}{ 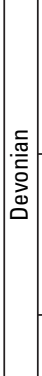 } & & & 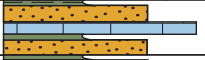 & 376 & At the base, greenish-gray and reddish-gray sandstone, silts \\
\hline & $U$ & $\frac{\bar{\sigma}}{\stackrel{\bar{y}}{*}}$ & 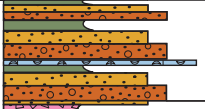 & $\begin{array}{l}300- \\
1,200\end{array}$ & $\begin{array}{l}\text { Red conglomerates at base, red polymictic sandstone, mudst } \\
\text { limestone }\end{array}$ \\
\hline & $\mathrm{M}$ & $\frac{\frac{\pi}{\pi}}{\frac{\pi}{N}}$ & 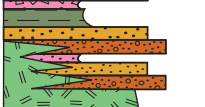 & $1,000-$ & $\begin{array}{l}\text { Red conglomerates, tuffaceous conglomerates, red sandston } \\
\text { the south, these rocks are replaced by rhyolite porphyry, fel } \\
\text { tuffs. Lenses of amygdaloidal rocks and plagioclase porphy }\end{array}$ \\
\hline & L & $\underset{\substack{\bar{\pi} \\
\frac{\pi}{\pi}}}{\underline{\pi}}$ & 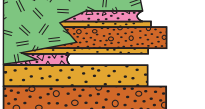 & $\begin{array}{c}650- \\
900\end{array}$ & $\begin{array}{l}\text { Green- and gray-pyroxene and plagioclase porphyries, tuff br } \\
\text { tuffaceous conglomerates. Greenish- and reddish-gray san } \\
\text { conglomerates at the base }\end{array}$ \\
\hline
\end{tabular}

Figure 3. Correlation chart for the Chu-Sarysu Basin (Box and others, 2012), the western Teniz Basin, and the Zharysbay area, eastern Teniz Basin, Kazakhstan (Syusyura and others, 2010). Stratigraphic columns are correlated at the base of the Vladimirov and Dzhezkazgan Formations (indicated by horizontal green lines) which are several upward-fining clastic sequences above Lower Carboniferous platform carbonates. 
imestone, thinning to southeast

and gray limestone

Zharysbay area, eastern Teniz Basin

ay limestone, thinning to

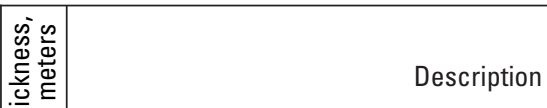

sandstones, siltstones

calations, and thin ing to northeast

thinning to northeast

mudstone, and siltstone

ne with interbedded calcareous

rates include chert

one, and dark-gray mudstone

one, and thin layers of

es, and tuffaceous sandstones. In sites, quartz albitophyre, and their ries

eccias, and

dstone, and

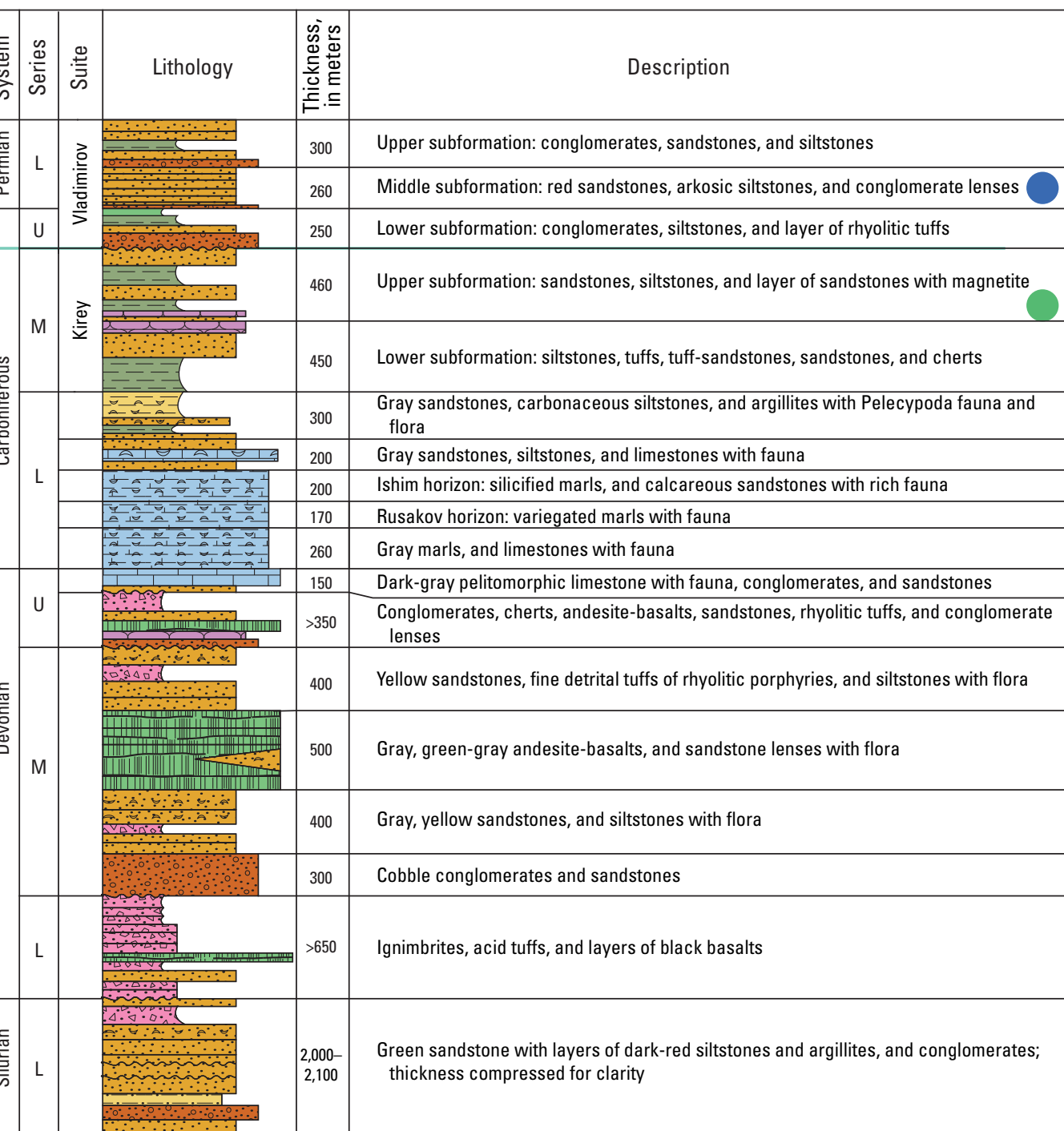




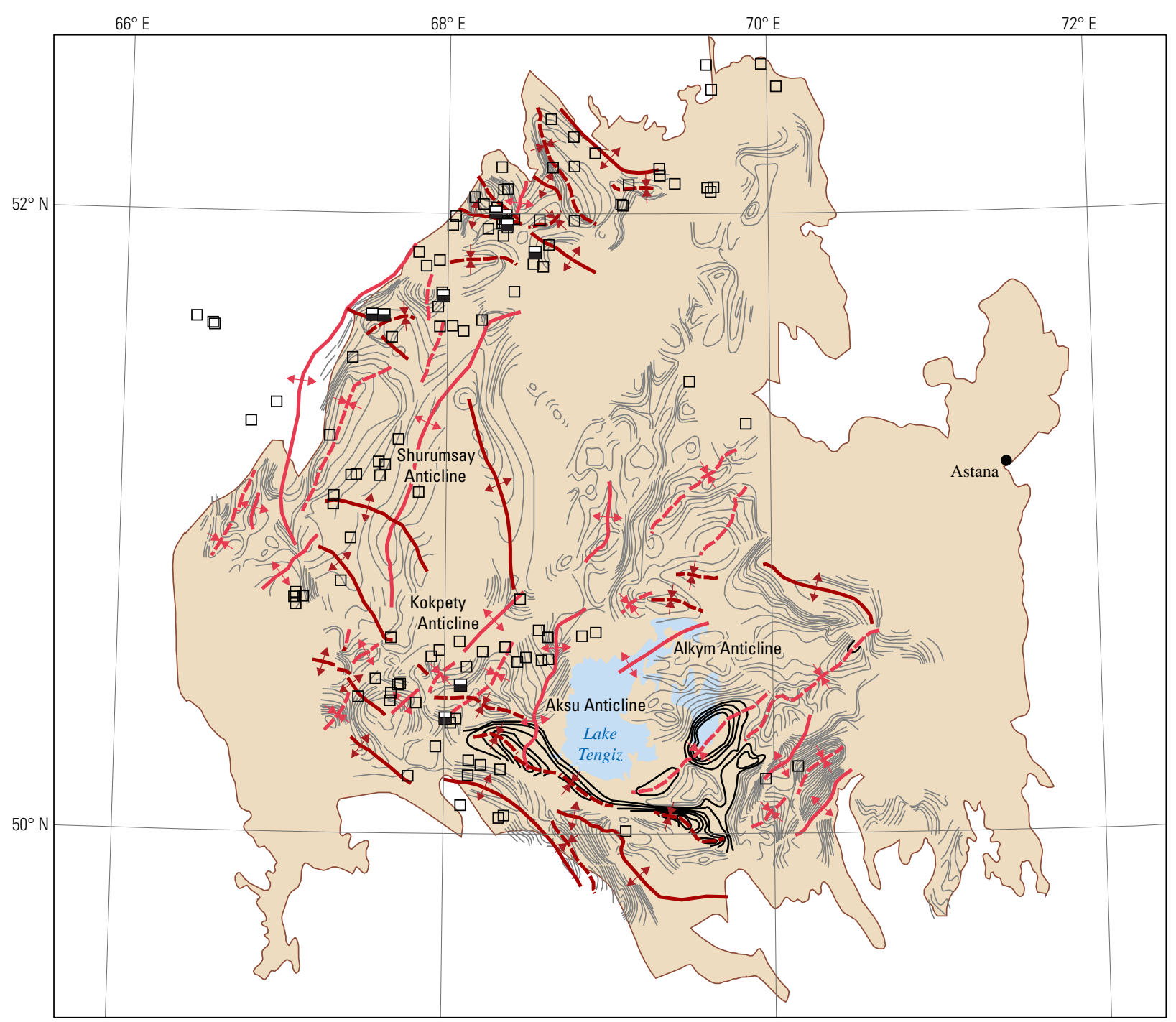

Political boundaries from U.S. Department of State (2009). Asia North Albers Equal Area Projection.

Central meridian, $69^{\circ} \mathrm{E}$., latitude of origin, $30^{\circ} \mathrm{N}$.
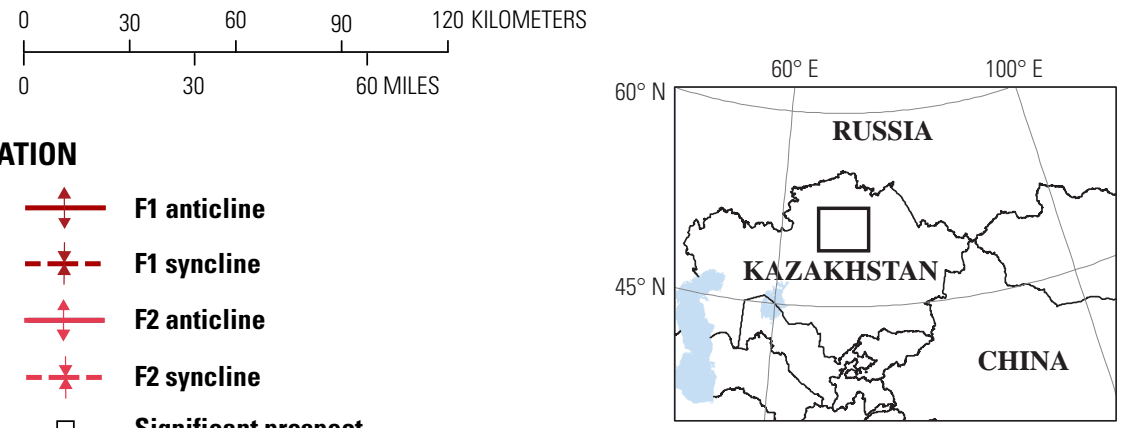

EXPLANATION
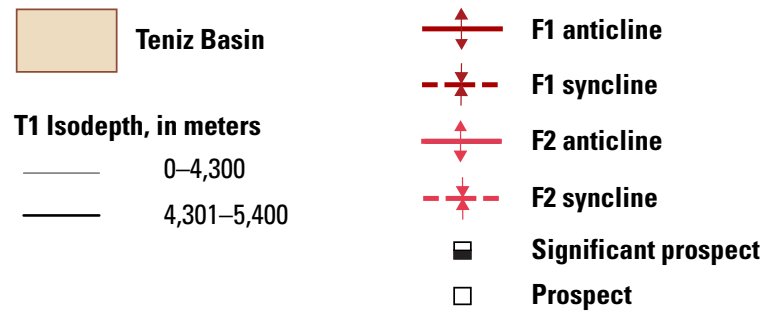

Figure 4. Map showing contours of the $T_{1}$ reflecting horizon (Syusyura and others, 2010), traces of fold axes, and sedimenthosted stratabound copper prospects in the Teniz Basin, Kazakhstan. The extent of the Teniz Basin is from Fugro Robertson, Ltd. (2008). 

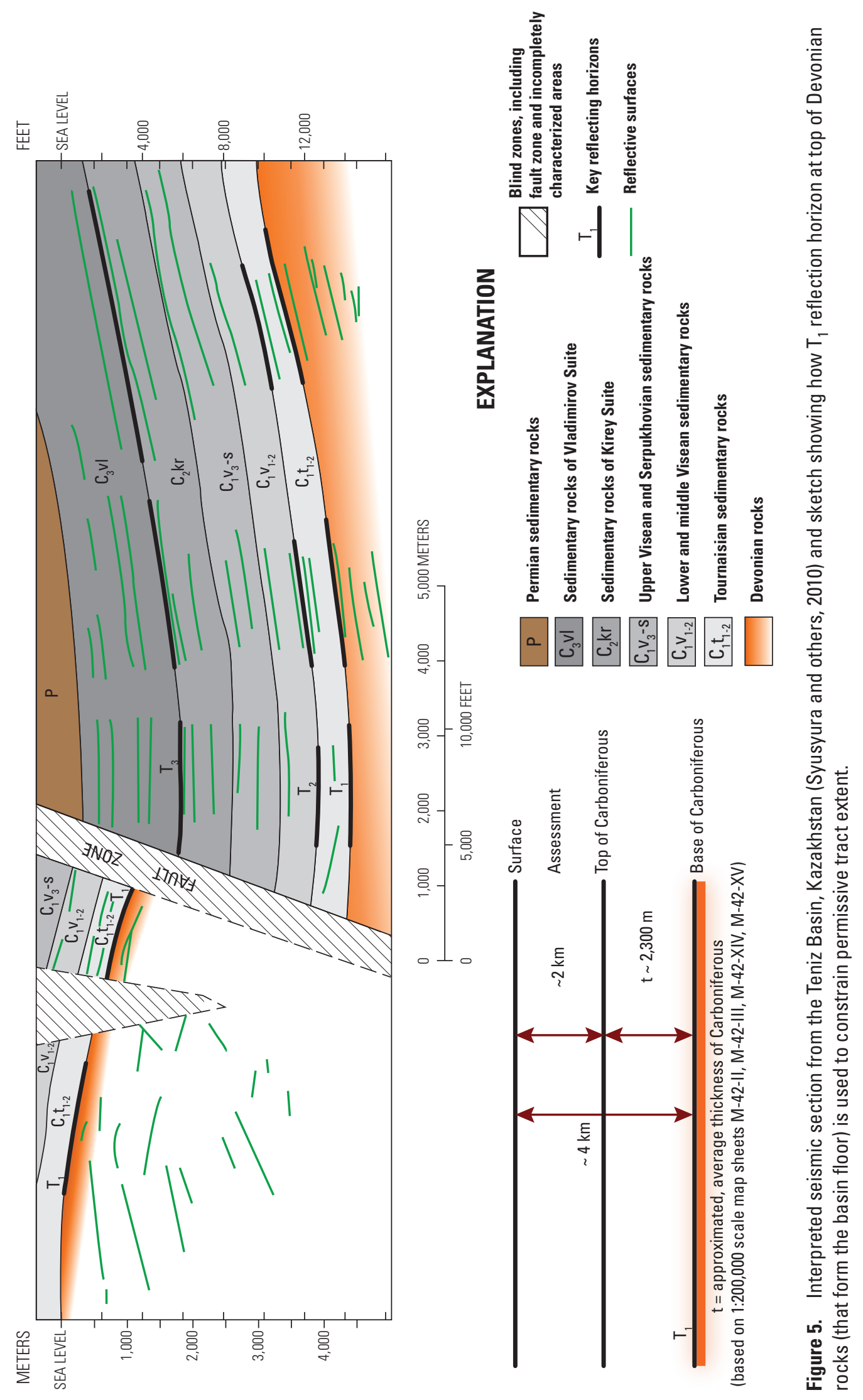


\section{Delineation of Permissive Tracts}

Ore deposits represent the ultimate focal points of much larger-scale systems of energy and mass flow, and mineral system models are used to systematically organize our ideas about ore deposit genesis in the context of larger Earth systems. In order to map areas where undiscovered deposits may occur, we first need evidence that an ore-forming system was present. Next, we must identify spatial positions where an ore-forming system is predicted to have formed undiscovered deposits.

Variations of the source-transport-trap paradigm are used to define both petroleum and mineral systems (Magoon and Dow, 1994; Wyborn and others, 1994; Magoon and Schmoker, 2000). Petroleum exploration and assessment uses a system that considers the following elements and processes essential to petroleum accumulation: source rocks, maturation of source rocks to generate oil, oil migration (transport), and reservoir rocks that trap and seal hydrocarbons (Magoon and Dow, 1994). Similarly, given the late diagenetic ore theory, formation of sediment-hosted stratabound copper deposits in sedimentary basins requires a metals source, a fluid that extracts and moves metals away from source rocks, a pathway that allows movement of ore-bearing fluids, and a physical and redox chemical trap that fixes metals in an ore body (Taylor, 2000; Hitzman and others, 2005; Hayes and others, 2012). Essentially, the same elements, processes, and timing required to create a total petroleum system (Magoon and Schmoker, 2000) are also required of an ore system to form sedimenthosted stratabound copper deposits. The timing of processes that control fluid generation, migration, accumulation, and preservation is critical. If a single element or process is missing or occurs out of order, viable accumulations of copper cannot form.

In this USGS global mineral resource assessment, areas with potential for sediment-hosted stratabound copper deposits are mapped if they possess the following geological characteristics: (1) aquifer facies red bed rocks juxtaposed against strata that contain reductants (typically organic material and earliest diagenetic pyrite); (2) a basin history indicative of rock burial and diagenesis (depths of $1-5 \mathrm{~km}$ at temperatures ranging from 70 to $220^{\circ} \mathrm{C}$ ); and (3) evidence that copper-enriched solutions were present in the basin. Maps, cross sections, and stratigraphic sections are used to map hydrologically-conductive sequences of rock with stratigraphic relationships consistent with sandstone subtype facies. Copper-mineralized rock, burial history, and copper in subsurface waters all indicate copper enrichment of solutions occurred.

Middle and Upper Carboniferous and Permian sedimentary rocks within the greater extent of the Teniz Basin have attributes favorable for hosting sandstone subtype and red bed type deposits (figs. 2 and 6) and to a lesser extent, reduced-facies copper deposits. The lowermost red bed unit, the Lower and Middle Carboniferous Kirey Suite (210-1,200 m thick), consists of red sandstone, mudstone, with tuffaceous and siliceous interbeds, and thin dark-gray limestone. Tabular gypsum crystals are found in some limestone beds. This suite is overlain by the Middle to Upper Carboniferous Vladimirov Suite (700-1,900 m thick), which consists of several upward-fining sequences made up of red crossbedded conglomeratic sandstone, siltstone, and mudstone capped by thin layers of gray limestone (fig. 2). The Lower Permian Kayraktin Suite is characterized by alternating layers of reddish-brown sandstone, siltstone, mudstone, and gray limestone. Rock salt and anhydrite are reported in the Kayraktin Suite (Marochkin and others, 1994). The Kayraktin Suite ranges in thickness from $400 \mathrm{~m}$ in the northwest part of the basin to $1,700 \mathrm{~m}$ in the southeast. The overlying Lower Permian Kiymin Suite (300-1,000 m thick) generally consists of reddish-brown sandstones, green siltstone, mudstone, and gray limestone. The uppermost unit, the Upper Permian Shoptykul Suite (200-800 m thick), includes red-brown to brownish-green sandstone, gray limestone, and siltstone.

In the Teniz Basin, aquifer-facies red bed rocks include conglomeratic sandstones of the Vladimirov Suite that were deposited in fluvial or shallow-water marine depositional environments. In sandstone subtype copper deposits, reduced rocks are former aquifer and reservoir facies red bed rocks that were exposed to petroleum. Reduction of ferric iron phases by reaction with petroleum resulted in bleaching of the former red beds to white, light-gray, or pastel green. Fourteen potentially ore-bearing intervals of gray beds (inferred by us to be bleached red beds) have been recorded in the Vladimirov Suite (Bogdanov and Feoktistov, 1972). Sandstones in the upper part of the underlying Kirey Suite and the lower part of the overlying Kayraktin Suite are also permissive host rocks. Rocks of the Vladimirov Suite likely underwent burial diagenesis at appropriate depths and temperatures because these strata are overlain by 900-3,500 m of younger Permian sedimentary rocks. Finally, the widespread distribution of copper prospects and occurrences in Carboniferous and Permian rocks throughout the basin provides direct evidence for the presence of copper-enriched subsurface water.

A permissive tract was delineated for the Teniz Basin based on the distribution of the Kirey, Vladimirov, and Kayraktin Suites as shown on geologic and isodepth maps compiled by Syusyura and others (2010). To further constrain permissive tract extent, we resolved where the top of the Vladimirov Suite occurred more than $2 \mathrm{~km}$ below the surface (the depth limit for this assessment). By adding the approximate thickness of Carboniferous strata (2,300 m) to the assessment depth $(2,000 \mathrm{~m})$, we were able to use the T1 isodepth map (base of Carboniferous) to construct the permissive tract by excluding areas where the $\mathrm{T} 1$ reflector is deeper than 4,300 $\mathrm{m}$. A volume of rock satisfying these criteria was defined and vertically projected to the surface to define the bounds of the permissive tract. 


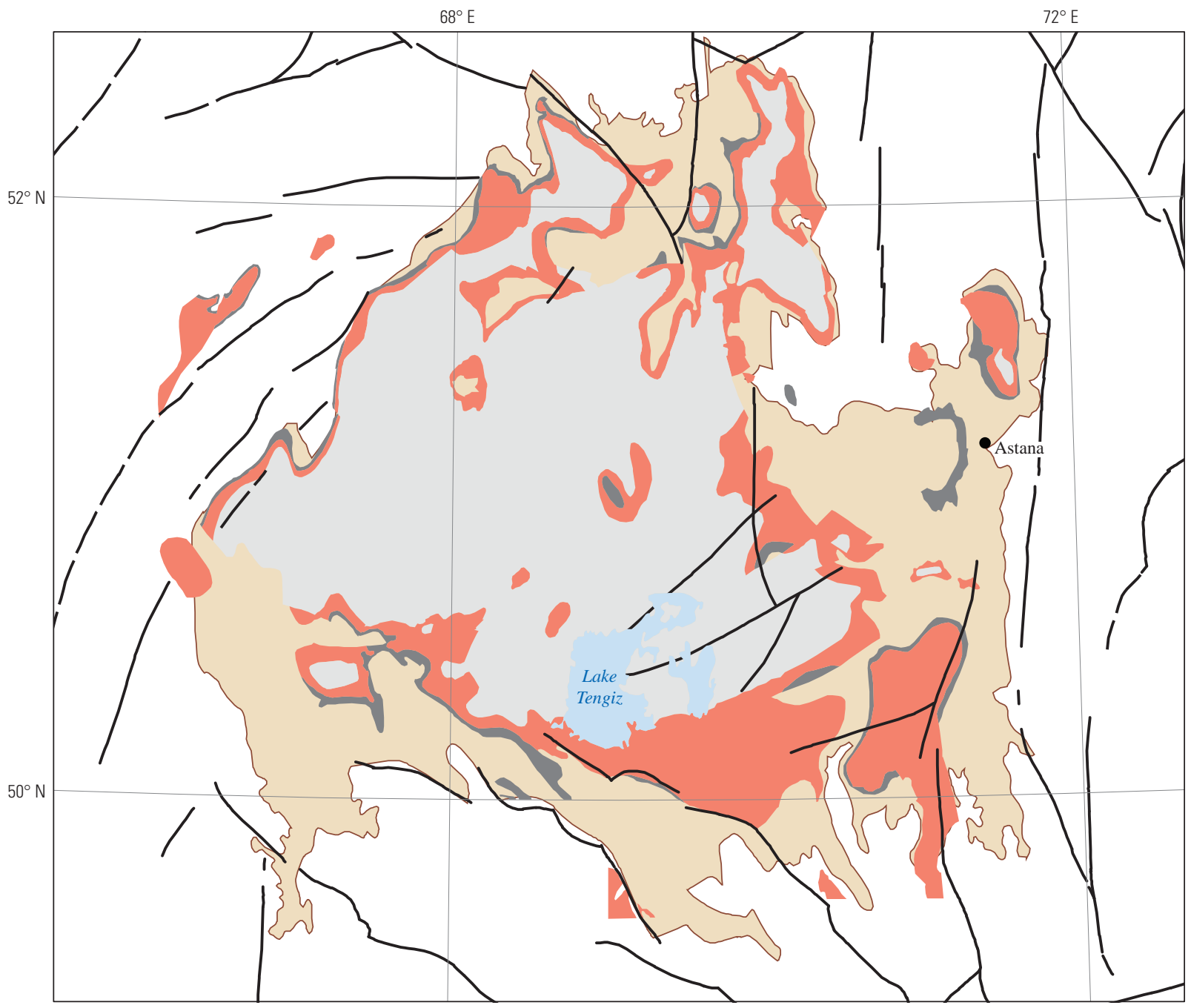

Political boundaries from U.S. Department of State (2009). Asia North Albers Equal Area Projection.

Central meridian, $69^{\circ} \mathrm{E}$., latitude of origin, $30^{\circ} \mathrm{N}$.

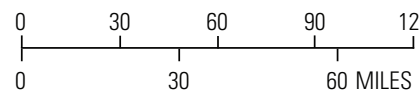

120 KILOMETERS

\section{EXPLANATION}

Lower-Upper Permian-Kayraktin, Kiymin, and Shoptykul Suites

Upper Carboniferous-Vladimirov Suite

Middle Carboniferous-Kirey Suite

Teniz Basin

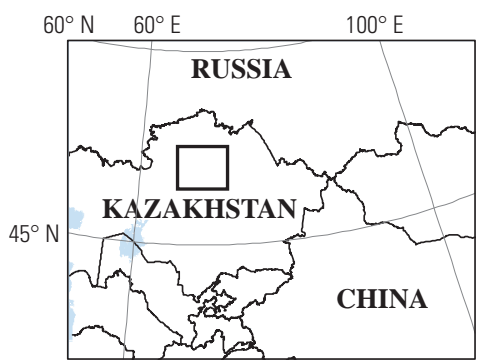

— Fault-Dashed where approximately located

Figure 6. Geologic map showing the extent of the Teniz Basin, Kazakhstan and the bedrock distribution of Carboniferous and Permian rock units (modified from Syusyura and others, 2010). 


\section{Sandstone Copper Deposits and Prospects}

No sites with reported mineral inventory or past production are known in the study area; therefore, no mineralized areas qualify as “deposits,” and all mineralized sites are referred to as "prospects.” B. Syusyura (2008) states that most of the hundred or so small copper occurrences in the Teniz Basin are associated with gray sandstones and siltstones that contain coalified plant remains. On that basis, one could assume that all copper occurrences are of the red bed subtype of Lindsey and Cox (2003). However, a few site descriptions suggest the possibility that some or many of the copper occurrences are of the sandstone subtype. Without specific information regarding organic material in the rocks, we use depositional environment to classify sites according to deposit type. Occurrences in the Kiymin and Shoptykul Suites are classified as red bed subtype because information in stratigraphic columns and unit descriptions is consistent with an alluvial-fluvial-lacustrine depositional environment in which mineralization is likely confined to sand lenses that have restricted lateral extents. In contrast, occurrences in the Kiery, Vladimirov, and Kayraktin Suites are assigned to the sandstone subtype.

Only three intervals in the Middle Carboniferous and Permian stratigraphic sections host prospects (Bogdanov and others, 1973). The first interval is situated in the basal, upper section of the Vladimirov Suite and consists of cupriferous, greenish-gray, thin-bedded silty sandstones. The second interval is confined to sedimentary rocks of the lower section of the Kayraktin Suite. Copper sulfide disseminations are found in dark-gray argillites and clay slates interbedded with marls, and also in greenish-gray silty sandstones. The third interval occurs in the middle section of the Kayraktin Suite. In all of the copper-bearing intervals, the ore bodies have a lenticular shape, are arranged en echelon, and thin along-strike and down-dip (Bogdanov and others, 1973). The main sulfide minerals are bornite and chalcocite. Galena, chalcopyrite, and tennantite-tetrahedrite occur rarely. Finely-dispersed ores predominate. Copper sulfides occasionally are found in veins of calcite, but are generally absent in barite, celestine, and gypsum veinlets. Malachite and azurite are widespread in the oxidized zone.
Only six mineralized sites in the basin have geologic descriptions and four are summarized here. The Dzhezkazgan Geologic Research Expedition Exploratory found two small ore bodies with ore grade mineralization in the Tersakkan area of the southern Teniz Basin (Bogdanov and Feoktistov, 1972); we believe they are sites known subsequently as Kenen and Kopkazgan (B. Syusyura, 2008, written comm.; Seltmann and others, 2009). Both occurrences are located in the core of the Kokpekty anticline (fig. 5). The Kenen prospect, in rocks near the base of the Kayraktin Suite, has three fragmented ore bodies in a reduced, gray sandstone that is rhythmically interbedded with red-colored silty mudstones. The ore body does not exceed $1 \mathrm{~m}$ in thickness and has an average grade of about 0.5 percent copper. Mineralization at the Kopkazgan prospect is found in gray rocks that constitute the upper part of the Vladimirov Suite. Ore-bearing intervals are $0.75-7.3 \mathrm{~m}$ thick and can be traced 500-900 m along-strike and up to $200 \mathrm{~m}$ down-dip. Copper grades range from 0.88 to 1.75 percent. Organic material associated with these deposits was not described.

Copper mineralization at two other sites, Borisovskoe and Kiyminskoe, is localized by carbonized plant remains (Bogdanov and others, 1973), indicating they are best categorized as red bed type deposits of Lindsey and Cox (2003) or the Urals (lacustrine-alluvial) type of Bogdanov and others (1973). Copper mineralization at the Borisovskoe occurrence in the Vladimirov Suite is concentrated in a 10-m-thick unit consisting of interbedded gray and greenish-gray sandstones and argillites. Intense malachite mineralization is confined to interlayers rich in carbonized plant remains. The primary sulfide mineral in this deposit is chalcopyrite (Bogdanov and others, 1973). The Kiyminskoe occurrence is associated with red beds of the Lower Permian Kiymin Suite where copper mineralization is confined to two horizons that are nearly $200 \mathrm{~m}$ apart stratigraphically. The lower ore interval is $0.4-1.5 \mathrm{~m}$ thick and consists of greenish-gray fine-grained sandstones with films of malachite. The sandstones form lenses that extend 35-95 m along strike. Fossil impressions of Calamites are a common characteristic of the host rock. The upper ore interval is a 1-8 m thick interval of greenish-gray, fine-grained sandstones and argillites. Copper mineralization is confined to several discrete sandstone lenses measuring 1-5 m thick. Malachite and azurite are concentrated in thin interlayers that are enriched with accumulations of carbonized plant remains (Bogdanov and others, 1973). 


\section{Development of the Prospects Database}

Multiple data sources about mineralized areas were used to develop a prospects database. The number of points and quality of attribution varied among them. The 1:200,000scale maps of mineral resources of USSR, Ulutau-Kokchetav series (Mikhailov, 1951, 1963; Mazarovich, 1958b; Minervin, 1961b; Vavic and Rosen, 1963; Babi'chev and others, 1970b) are the primary sources used for subsequent compilations, in particular the 1:1,000,000-scale map of mineral resources for the Tselinograd-Akmola sheet (Marochkin and others, 1994); the 1:1,500,000-scale compilation of geologic and minerals information for central Asia (Seltmann and others, 2009); and a 1:1,500,000-scale compilation published by Syusyura and others (2010). Previous national or global compilations contained only 10-16 records for the Teniz Basin (Rundkvist, 2001; Kirkham and others, 1994, 2008; Cox and others, 2003). No datasets provided tonnage or grade data; however, sites were categorized as a deposit, mineral occurrence, or mineral point in five datasets (table 2). Site names were available in three compilations. Locations for a same-named feature were not consistent among datasets and differed by more than $10 \mathrm{~km}$ in the worst cases.

We compiled a database of about 120 prospects among the various datasets. If a spatially coherent cluster of sites was judged to represent the same feature, then the location considered most reliable was the one shown on the 1:200,000scale mineral deposit maps (fig. 7). Consistent attributes were transferred to our database and were supplemented with information from geologic maps and Google Earth imagery. Prospects are shown in relation to the permissive tract for the Teniz Basin on figure 8.

Sites consistently referred to as "deposits" in previous compilations are coded as "significant prospects" in our compilation (table 3). In each source dataset, localities coded as deposits were categorized as small. We suspect grade and tonnage must have been estimated for these sites in order for them to be categorized by size but have been unsuccessful in finding data for these sites.

Table 2. Categorization of sediment-hosted stratabound copper occurrence in data sources used to compile a prospects database for this assessment.

[Counts are for those points that fall within the extent of the permissive tract. Sources for Ulutau-Kokchetav Series minerals maps are Babi'chev and others (1970b); Mazarovich (1958b); Mikhailov (1951, 1963); Minervin (1961a,b); Vavic and Rosen (1963); -, no data]

\begin{tabular}{|c|c|c|c|c|c|}
\hline $\begin{array}{l}\text { Source } \\
\text { (scale) }\end{array}$ & $\begin{array}{c}\text { Ulutau-Kokchetav } \\
\text { series minerals maps }{ }^{1} \\
(1: 200,000)\end{array}$ & $\begin{array}{c}\text { Marochkin and } \\
\text { others }(1994)^{2} \\
(1: 1,000,000)\end{array}$ & $\begin{array}{c}\text { Syusyura and } \\
\text { others }(2010)^{3} \\
(1: 1,500,000)\end{array}$ & $\begin{array}{c}\text { Seltmann and } \\
\text { others }(2009)^{4} \\
(1: 1,500,000)\end{array}$ & $\begin{array}{c}\text { Rundkvist } \\
(2001)^{5} \\
(1: 2,500,000)\end{array}$ \\
\hline Small deposit & - & 3 & 3 & 3 & 3 \\
\hline Non-industrial & 3 & - & - & - & - \\
\hline Mineral occurrence & 43 & 28 & 83 & 72 & 7 \\
\hline Mineralization point & - & 48 & - & 19 & - \\
\hline
\end{tabular}

${ }^{1} 1: 200,000$-scale maps: Kenen, Altynkazgan, Kiyminskoe.

${ }^{2}$ Marochkin and others (1994): Kenen, Kiyminskoe, Borisovskoe.

${ }^{3}$ Syusyura and others (2010): Kenen, Kopkazgan, Proletarskoe.

${ }^{4}$ Seltmann and others (2009): Kopkazgan, Altynkazgan, Kieilin.

${ }^{5}$ Rundkvist (2001): Kopkazgan-Kenen, Kiyminskoe, Spasskoe. 


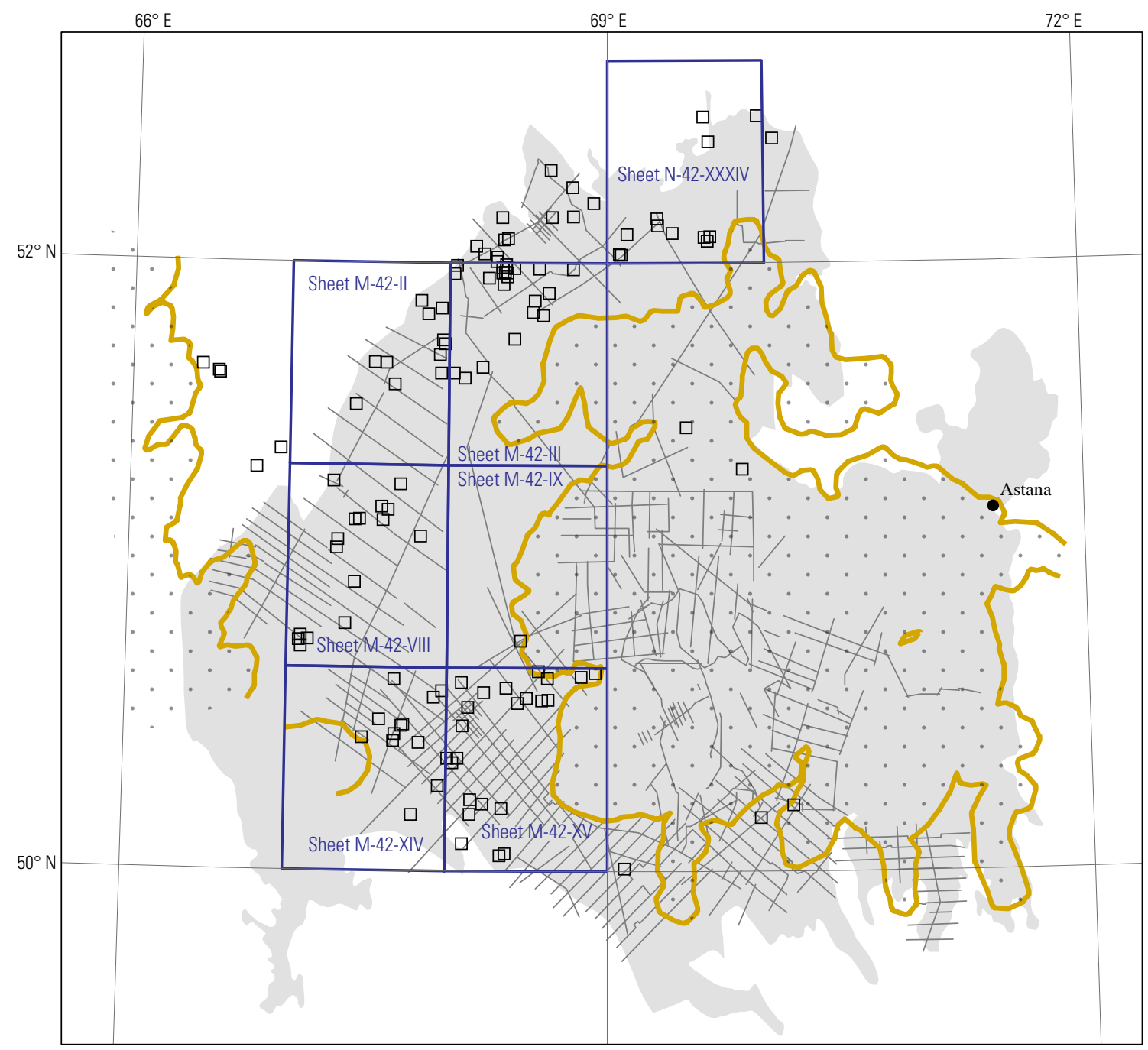

Political boundaries from U.S. Department of State (2009). Asia North Albers Equal Area Projection.

Central meridian, $69^{\circ} \mathrm{E}$., latitude of origin, $30^{\circ} \mathrm{N}$.

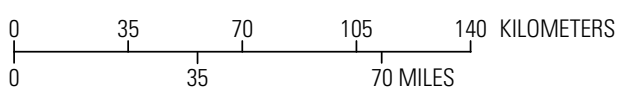

EXPLANATION
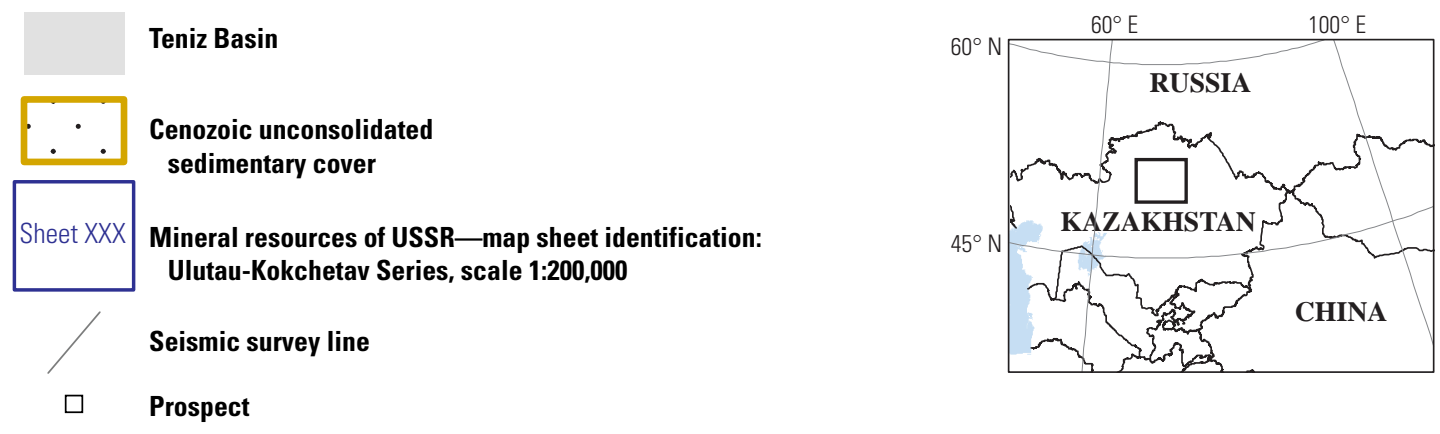

Figure 7. Map showing location of 1:200,000-scale geological and mineral resource map sheets used in this study relative to extent of Teniz Basin, Kazakhstan (Fugro Robertson, Ltd., 2008), extent of Cenozoic cover (Syusyura and others, 2010), location of prospects, and seismic survey lines (Syusyura and others, 2010). 


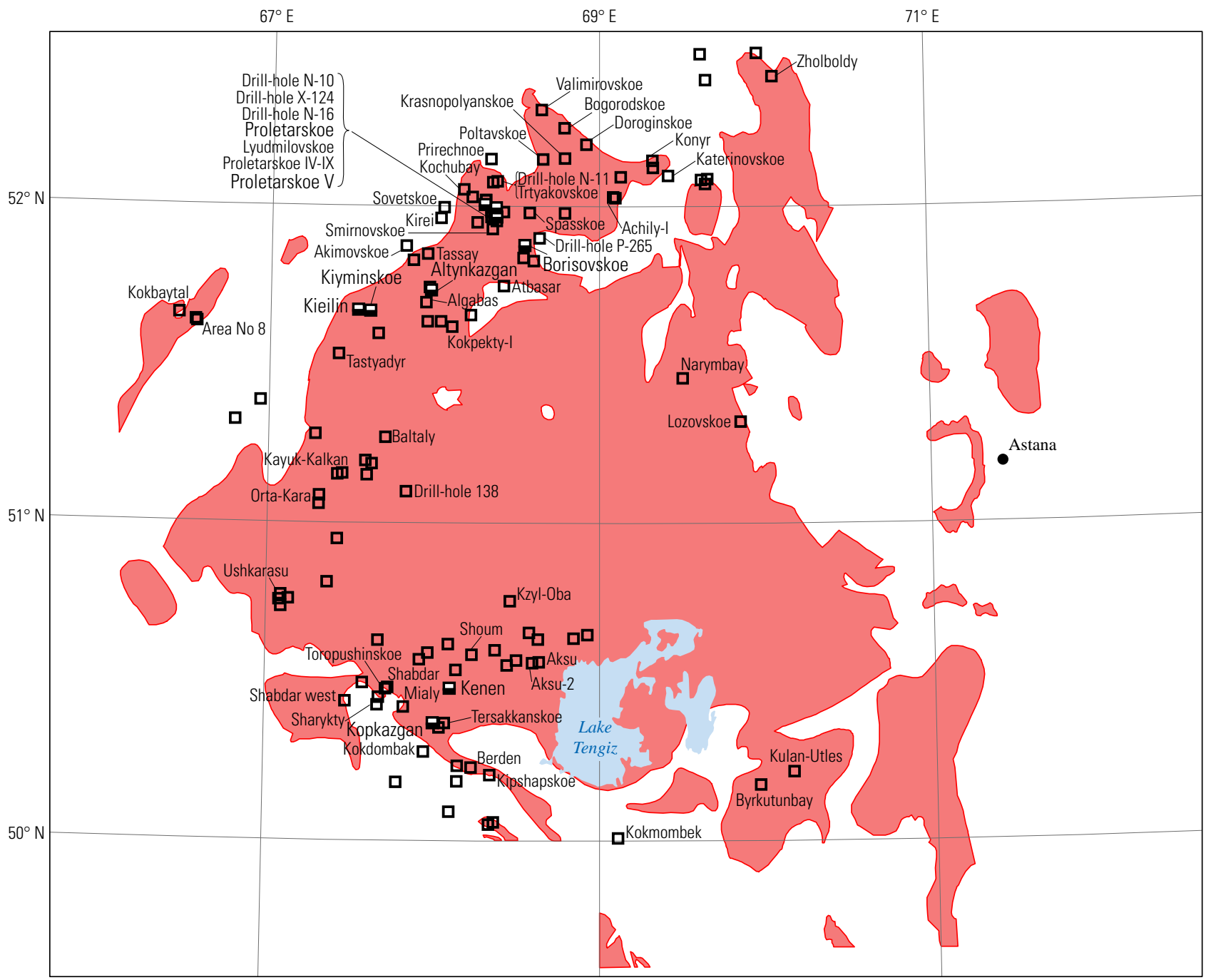

Political boundaries from U.S. Department of State (2009). Asia North Albers Equal Area Conic Projection. Central meridian, $69^{\circ} \mathrm{E}$., latitude of origin, $30^{\circ} \mathrm{N}$.

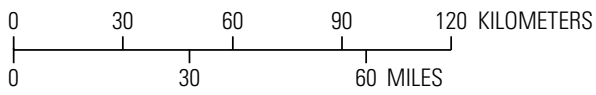

\section{EXPLANATION}

Sediment-hosted sandstone copper

Assessed sandstone copper tract 142ssCu8050

口 Sandstone copper significant prospect

$\square \quad$ Sandstone copper prospect

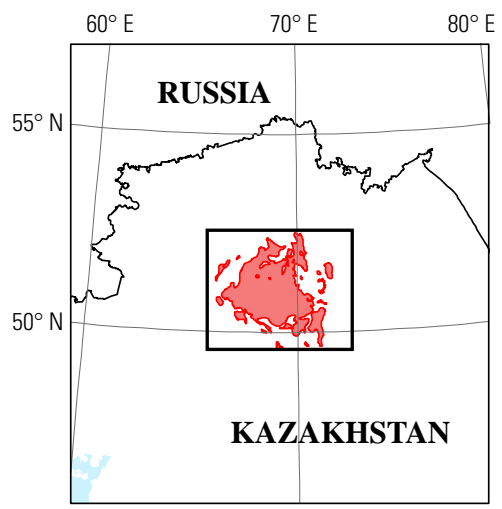

Figure 8. Map showing location of permissive tract 142ssCu8050 (TZ-1) and known prospects, Teniz Basin, Kazakhstan. Detailed descriptive information is available in both the GIS database and in tables 2 and 3. 
Table 3. Significant Upper Carboniferous and Lower Permian sandstone copper prospects, Teniz Basin, Kazakhstan.

\begin{tabular}{|c|c|c|c|c|}
\hline Name & $\begin{array}{l}\text { Latitude } \\
\text { (N) }\end{array}$ & $\begin{array}{l}\text { Longitude } \\
\text { (E) }\end{array}$ & $\begin{array}{c}\text { Geologic map unit at point } \\
\text { location outcrop }\end{array}$ & Reference \\
\hline Unnamed & 51.9948 & 68.3585 & Vladimirov Suite & Babi'chev and others (1970b) \\
\hline Borisovskoe & 51.8758 & 68.541 & Vladimirov Suite & Babi'chev and others (1970b), Bogdanov and others (1973) \\
\hline Kieilin & 51.6705 & 67.5291 & Kayraktin Suite & Mikhailov and Litvinovich (1963) \\
\hline Proletarskoe & 52.0054 & 68.2955 & Vladimirov Suite & Syusyura and others (2010) \\
\hline Proletarskoe V & 51.9662 & 68.3663 & Vladimirov Suite & Babi'chev and others (1970b) \\
\hline
\end{tabular}

\section{Grade and Tonnage Model for Sandstone Copper Deposits}

Because grade and tonnage data are not available for prospects in the Teniz Basin area, a global grade and tonnage for 70 sandstone subtype copper deposits is used in this assessment (appendix B). Mean and median values for ore tonnage are 77 and 10 million metric tons, respectively (fig. 9). Mean and median copper grades are 1.4 and 1.2 percent. Distributions of ore tonnage, copper grade, and contained copper are all positively skewed and consistent with a lognormal model. Cobalt and silver are important coproducts of some sediment-hosted stratabound copper deposits, but concentration data are missing for 96 and 73 percent, respectively, of the cobalt and silver deposits used for the global database. Log-transformed values of copper and cobalt grades do not show significant correlation with logtransformed values of tonnage.

\section{Estimate of the Number of Undiscovered Deposits}

All components and processes necessary for sedimenthosted stratabound copper ore system formation are present in the Teniz Basin. Red bed sediments or mafic volcanic rocks, such as the Early and Middle Devonian volcanic sequence that floors the basin, could be copper sources in the basin. Oxidized brines, derived from evaporitic rocks interbedded with the red beds, are capable of leaching and transporting metals from red bed sediments and volcanic rocks because of their high oxidation state and high anion concentration. Residual brines, formed through dewatering in response to sediment loading, and capable of dissolving and transporting copper in solution, may have become chloride- and sulfate-enriched by moving through the thick Permian Kayraktin and the Lower to Middle Carboniferous Kirey Suites (southern part of basin) in which tabular gypsum (anhydrite) minerals have been reported (Zharkov, 1988) (table 1). Widespread mineral occurrences indicate that formation waters redistributed copper within the basin. Hydrocarbon accumulation in the aquifer facies rocks, at the time of copper mineralization, is possible. Potential petroleum source rocks include Lower Carboniferous bituminous carbonate units and Lower Carboniferous coalbearing units found near the southern margin of the basin (Oil \& Gas Journal, 1995; Kushev, 1963). The 14 horizons of gray beds (red beds bleached by migrating hydrocarbons) in the Valdimirov Suite resemble, in appearance and position, gray beds in the Chu-Sarysu Basin that are important ore hosts (Box and others, 2012). A methane show, from a Middle Carboniferous interval penetrated in a stratigraphic test hole, indicates that rocks in the basin locally developed hydrocarbon accumulations (Oil \& Gas Journal, 1995). 
$\boldsymbol{A}$

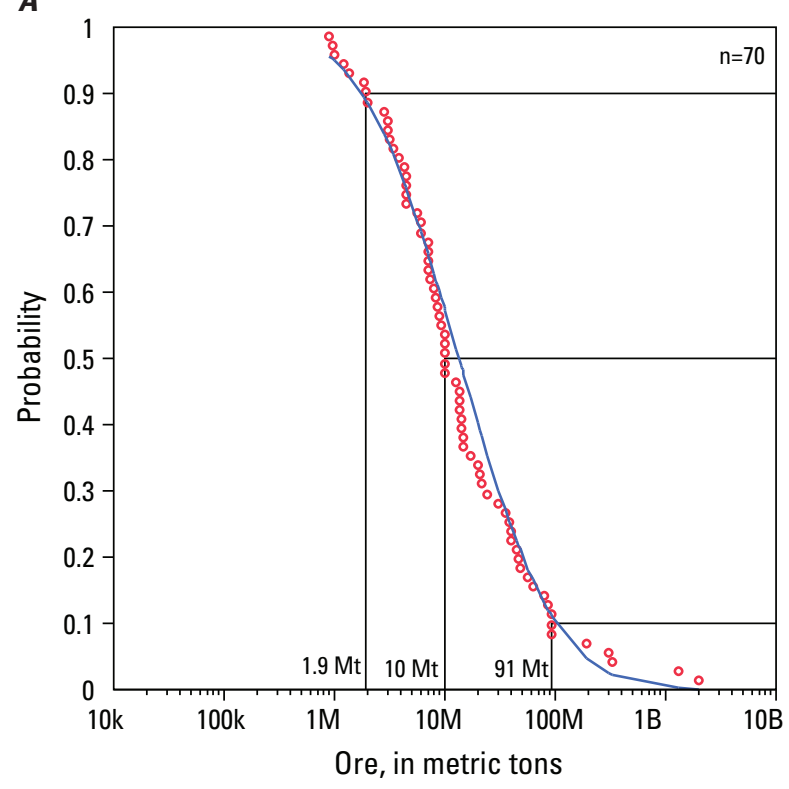

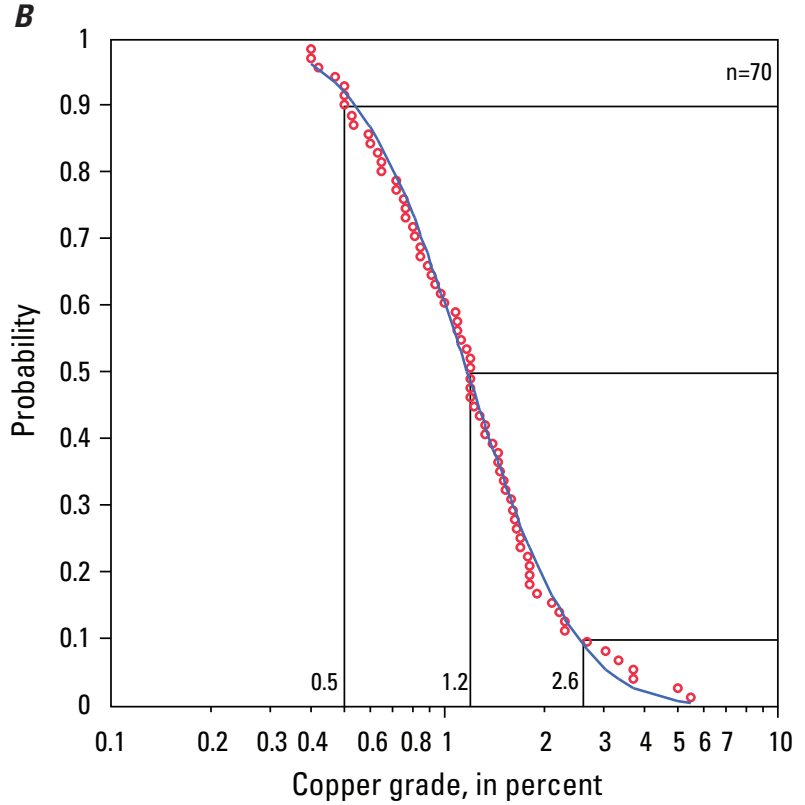

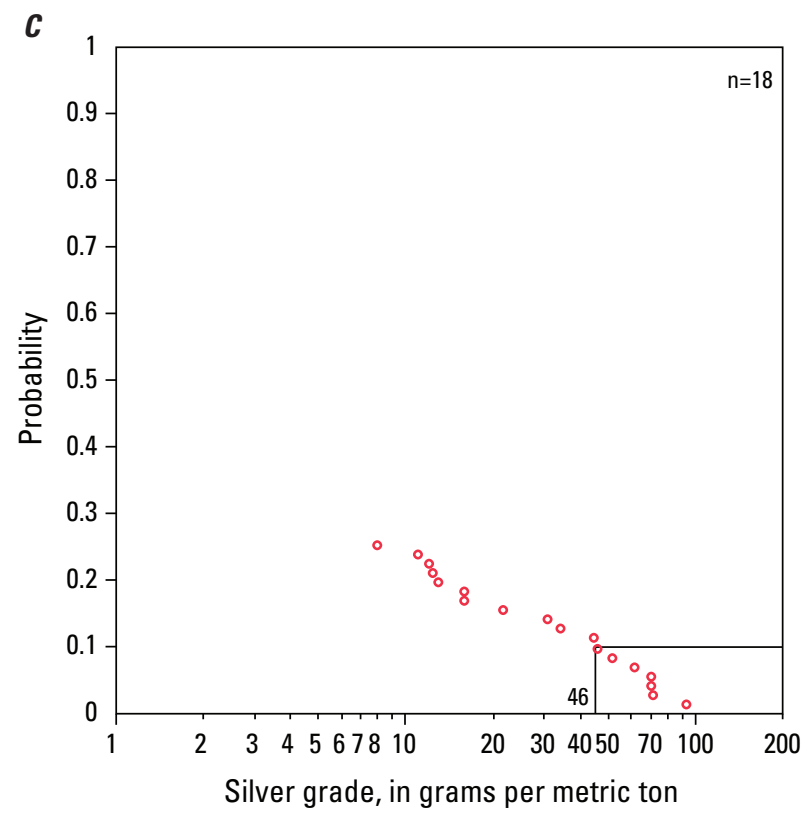

Figure 9. Cumulative frequency plots of ore tonnage $(A)$, copper grade $(B)$, and silver grade $(C)$, for 70 sedimenthosted sandstone copper deposits. Percentiles (10th, 50th, and 90th) of measured values are labeled along the $x$-axis. Each red circle is a data point for a deposit; the blue curve is the calculated lognormal distribution based on the population parameters of the data. Values for tonnage and grade for the 90th, 50th, and 10th probability values of the distribution are illustrated by extending a horizontal line from the vertical axis to the data curve, then drawing a vertical line to the horizontal axis. The value for the point where the vertical line intersects the horizontal axis is labeled. $\mathrm{k}=$ thousands, $\mathrm{M}=$ millions, $\mathrm{Mt}=$ million metric tons, $\mathrm{B}=\mathrm{billions}$. 
The association of known prospects and occurrences with anticlines and fault-related features suggests that structural traps, where petroleum may have accumulated, also controlled ore formation. The entire Kazakhstan area was under constant tectonic adjustment throughout the Paleozoic, as evident by the extensive suturing, faulting, folding, and refolding (Allen and others, 2001; Filippova and others, 2001). Any one or combination of deformation events could have initiated the flow of oxidizing brines, provided pathways for brines and reductants, and formed structural traps for copper mineralization.

Structures associated with known prospects and occurrences highlight the most prospective areas and help delineate areas with higher sediment-hosted stratabound copper mineral potential in the permissive tract. For example, fold structure traces and axes on a map we created from isodepth maps (fig. 4) correspond to, and sometimes follow trend with, copper prognostic areas defined in mapping by Syusyura and others (2010) (fig. 10). Seismic surveys show that similar structural features are present in the eastern part of the basin, where they are covered by younger sediments. Additional geophysical studies of the eastern Teniz Basin would facilitate evaluation of this underexplored area.

\section{Undiscovered Deposit Estimate}

In October, 2011, an expert panel (appendix D) met to estimate the number of undiscovered, sandstone subtype, sediment-hosted stratabound copper deposits in the permissive tract. After discussing the geology of the area and the deposit model, assessment team members made individual, subjective estimates of the minimum number of sandstone subtype copper deposits that could be present at three specified levels of certainty: 90 percent, 50 percent, and 10 percent. For example, on the basis of all available data, a team member might estimate a 90-percent chance of 1 or more, a 50-percent chance of 5 or more, and a 10-percent chance of 10 or more undiscovered deposits present in a permissive tract.

Each person made initial estimates without sharing results; then, results were compiled and discussed. This discussion almost always reveals information or insight not held by all panelists. Once team consensus was achieved, individual results were adjusted (table 4) and a consensus estimate was established for the simulation process (table 5; fig. 11). The consensus undiscovered deposit estimate reflects both the uncertainty and favorability of the tract (Singer, 1993; Singer and Menzie, 2010).

Final team estimates of undiscovered deposits are summarized in table 5, along with statistics that describe mean expected numbers of undiscovered deposits, the standard deviation and coefficient of variation associated with the estimate, and the number of known deposits. The assessment predicts a mean of nine undiscovered sandstone subtype copper deposits in the Teniz Basin.

\section{Estimate Rationale}

The tract has nine identified significant prospects (table 3). Many of them are called small deposits in mineral occurrence compilations (tables 2 and 3 ) and we infer that a mineral inventory has been determined for some of them. Because we do not have grade and tonnage information, we consider them to be undiscovered deposits, and assign a high level of confidence to that designation. Four sites are described as small deposits in several of the mineral occurrence datasets; this information constrained the estimate to three deposits at the 90th percentile. The number of structures that could localize undiscovered deposits, the lack of exploration at depth in the western part of the basin, and the complete lack of exploration under shallow cover in the eastern part of the basin (fig. 7) led the team to estimate 20 deposits at the 10th percentile.

\section{Quantitative Assessment Simulation Results}

Probable amounts of undiscovered resources for the tract were estimated by combining consensus estimates for numbers of undiscovered sandstone-copper deposits with the sedimenthosted copper, sandstone subtype model (Zientek, Hayes, and Taylor, 2013) using the EMINERS program (Root and others, 1992; Duval, 2012). Simulation results are reported at selected quantile levels, along with the mean expected amount of metal, the probability of the mean, and the probability of no metal. The amount of metal reported at each quantile represents the least amount of metal expected. Results of the Monte Carlo simulation are presented with a cumulative frequency plot and histogram (figs. 12 and 13). The cumulative frequency plots show estimated resource amounts associated with cumulative probabilities of occurrence, as well as the mean, for copper and total mineralized rock tonnage.

\section{Discussion}

This probabilistic assessment of undiscovered sandstone subtype of sediment-hosted stratabound copper deposits in the Teniz Basin indicates that a modest amount of undiscovered resource may be present (table 6). The mean estimate of undiscovered copper resources in the study area is 8.9 million metric tons. By comparison, the Chu-Sarysu Basin has identified 27.6 million metric tons of copper resources, with a mean estimate of 60.5 million metric tons of undiscovered copper (Box and others, 2012).

Assessment results are consistent with previous evaluations of copper resource potential in the Teniz Basin. 


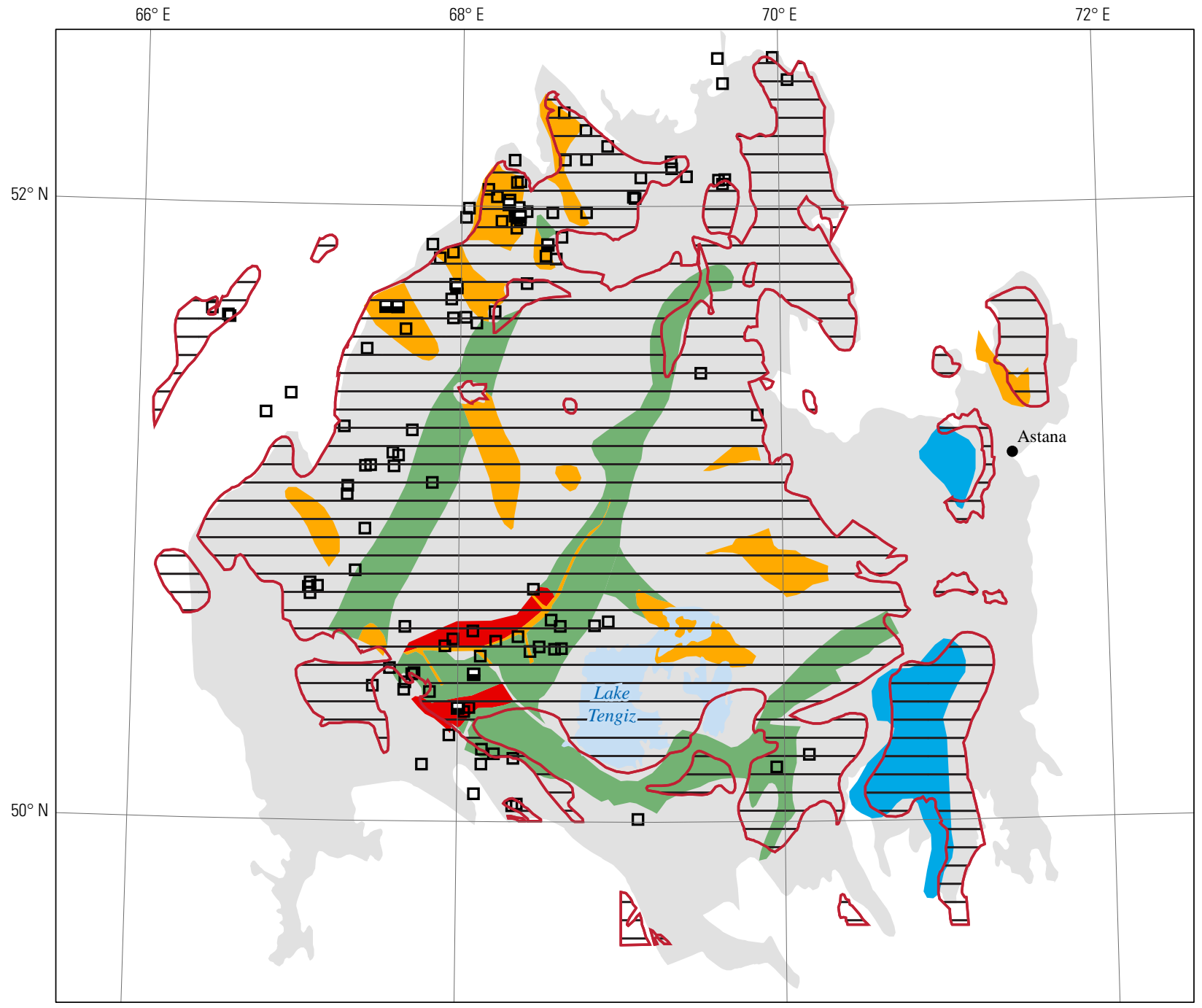

Political boundaries from U.S. Department of State (2009). Asia North Albers Equal Area Conic Projection. Central meridian, $69^{\circ} \mathrm{E}$., latitude of origin, $30^{\circ} \mathrm{N}$.

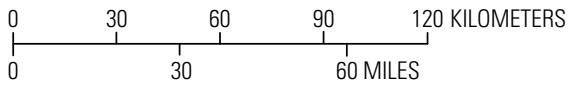

EXPLANATION

\begin{tabular}{|c|c|c|}
\hline & This study & Syusyura and others (2010) \\
\hline & $\begin{array}{l}\text { Permissive tract } \\
\text { 142ssc }\end{array}$ & Highly prospective \\
\hline & Teniz Basin & \\
\hline 口 & Significant prospect & 1st priority \\
\hline 口 & Prospect & $\begin{array}{l}\text { Prospective area, } \\
\text { 2nd priority }\end{array}$ \\
\hline & & $\begin{array}{l}\text { Area requiring additional } \\
\text { geophysical study }\end{array}$ \\
\hline
\end{tabular}

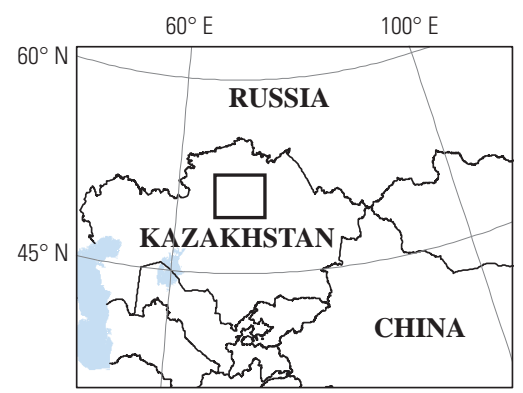

Figure 10. Map showing tract 142ssCu8050 (TZ-1) and prospects in relation to prospective areas as defined by Syusyura and others (2010). Extent of the Teniz Basin is from Fugro Robertson, Ltd. (2008). 
Table 4. Estimates by individual assessment team members of the number of undiscovered sandstone copper deposits in tract 142ssCu8050 (TZ-1), Teniz Basin, Kazakhstan.

[ $\mathrm{N}_{\mathrm{Xx}}$, estimated number of deposits associated with the xxth percentile; $\mathrm{N}_{\text {und }}$, expected number of undiscovered deposits; $\mathrm{S}$, standard deviation; $\mathrm{C}_{\mathrm{v}} \%$, coefficient of variance. $\mathrm{N}_{\text {und }}$, , and $\mathrm{C}_{\mathrm{v}} \%$ are calculated using a regression equation (Singer and Menzie, 2005)]

\begin{tabular}{llrlcccc}
\hline $\boldsymbol{N}_{\mathbf{9 0}}$ & $\boldsymbol{N}_{\mathbf{5 0}}$ & $\boldsymbol{N}_{\mathbf{1 0}}$ & $\boldsymbol{N}_{\mathbf{0 5}}$ & $\boldsymbol{N}_{\mathbf{0 1}}$ & $\boldsymbol{N}_{\text {und }}$ & $\boldsymbol{s}$ & $\boldsymbol{C}_{\mathbf{v}} \%$ \\
\hline 3 & 7 & 15 & 15 & 15 & 8 & 4.4 & 56 \\
3 & 7 & 12 & 12 & 12 & 7.1 & 3.3 & 47 \\
2 & 4 & 8 & 10 & 10 & 4.6 & 2.7 & 58 \\
3 & 5 & 20 & 20 & 20 & 8.7 & 6.5 & 75 \\
5 & 8 & 20 & 20 & 20 & 10 & 5.8 & 56 \\
\hline
\end{tabular}

Table 5. Consensus estimate of the number of undiscovered sandstone copper deposits in tract 142ssCu8050 (TZ-1), Teniz Basin, Kazakhstan.

$\left[\mathrm{N}_{\mathrm{xx}}\right.$, estimated number of deposits associated with the xxth percentile; $\mathrm{N}_{\text {und }}$, expected number of undiscovered deposits; $\mathrm{s}$, standard deviation; $\mathrm{C}_{\mathrm{v}} \%$, coefficient of variance; $\mathrm{N}_{\text {known }}$, number of known deposits in the tract that are included in the grade and tonnage model; $\mathrm{N}_{\text {total }}$, total of expected number of deposits plus known deposits; $\mathrm{N}_{\text {und }}$, , and $\mathrm{C}_{\mathrm{v}} \%$ are calculated using a regression equation (Singer and Menzie, 2005)]

\begin{tabular}{|c|c|c|c|c|c|c|c|c|c|}
\hline \multicolumn{5}{|c|}{ Consensus undiscovered deposit estimates } & \multicolumn{5}{|c|}{ Summary statistics } \\
\hline$N_{90}$ & $N_{50}$ & $N_{10}$ & $N_{05}$ & $N_{01}$ & $N_{\text {und }}$ & $s$ & $\boldsymbol{C}_{\mathrm{v}} \%$ & $N_{\text {known }}$ & $N_{\text {total }}$ \\
\hline 3 & 6 & 20 & 20 & 20 & 9.1 & 6.4 & 71.0 & 0 & 9.1 \\
\hline
\end{tabular}

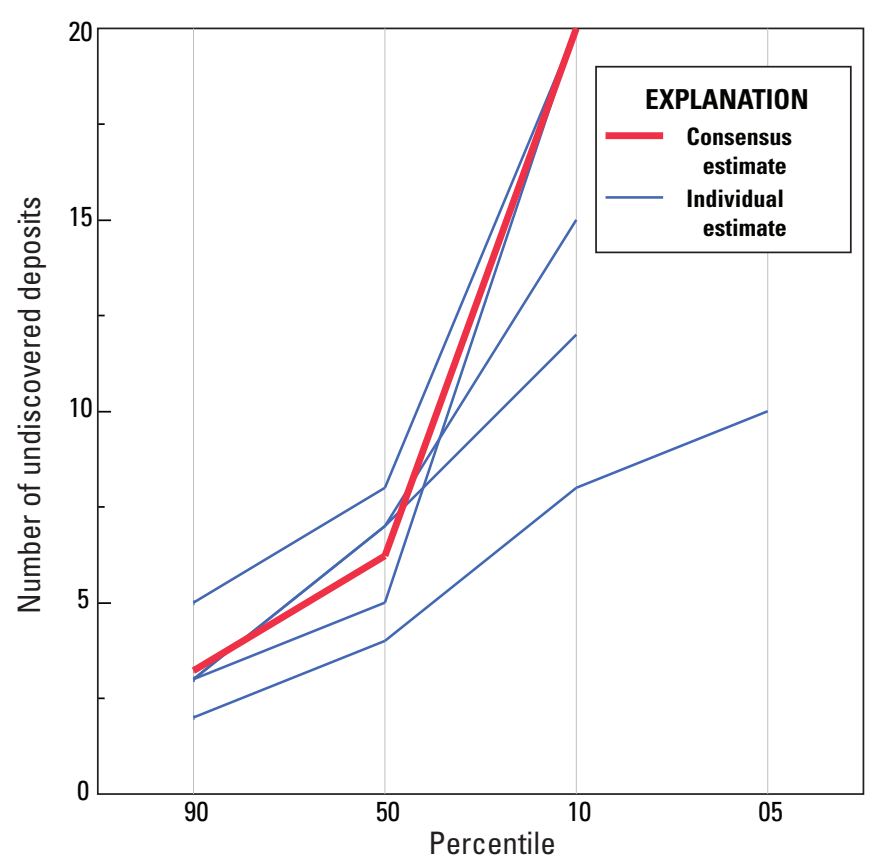

Figure 11. Graph comparing individual and consensus estimates of number of undiscovered sandstone copper deposits in tract 142ssCu8050 (TZ-1), Teniz Basin, Kazakhstan. 


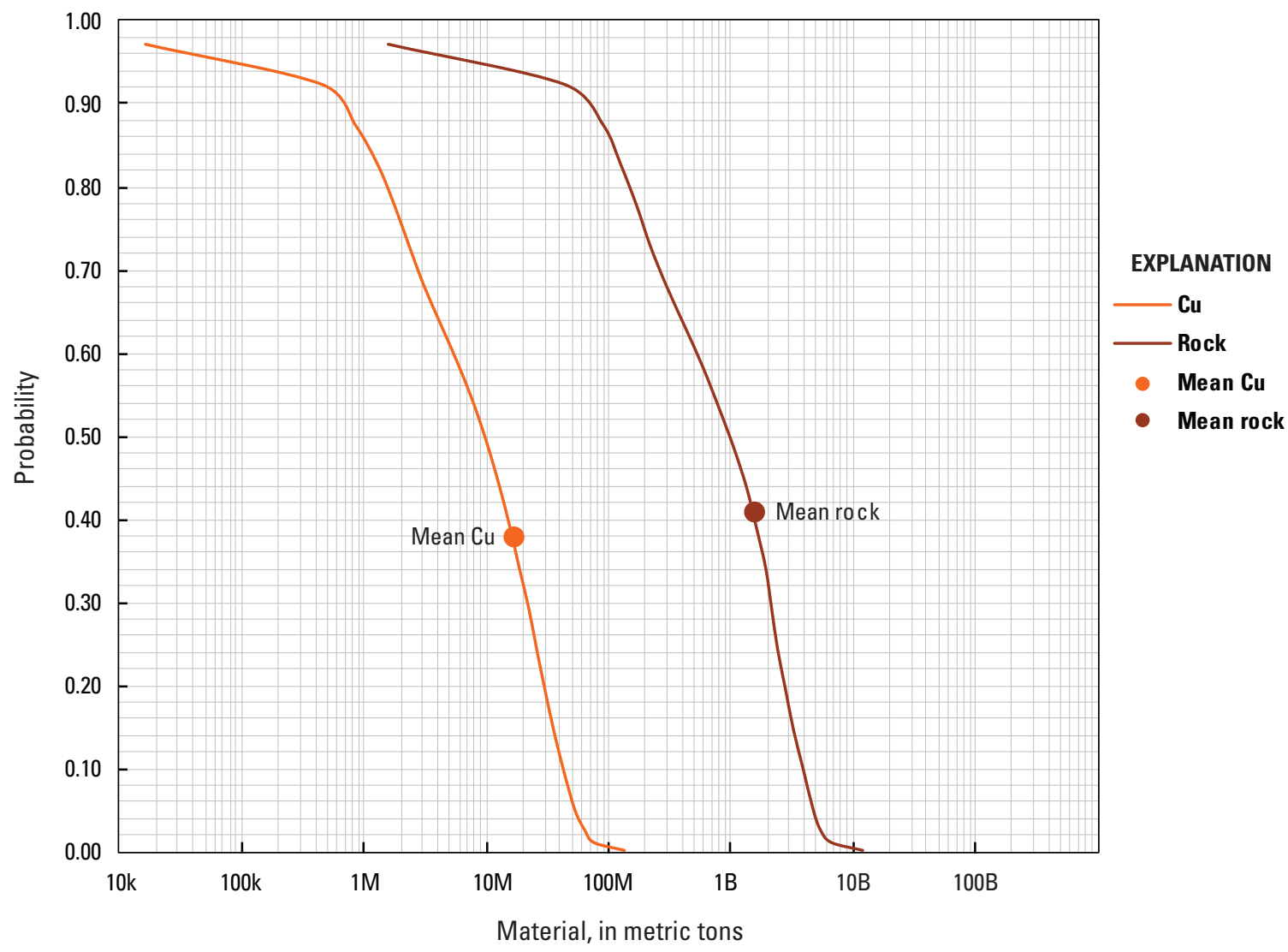

Figure 12. Cumulative frequency plot showing the results of a Monte Carlo computer simulation of undiscovered sandstone copper resources in tract 142ssCu8050 (TZ-1), Teniz Basin, Kazakhstan. k=thousands, $M=$ millions, $B=$ billions.

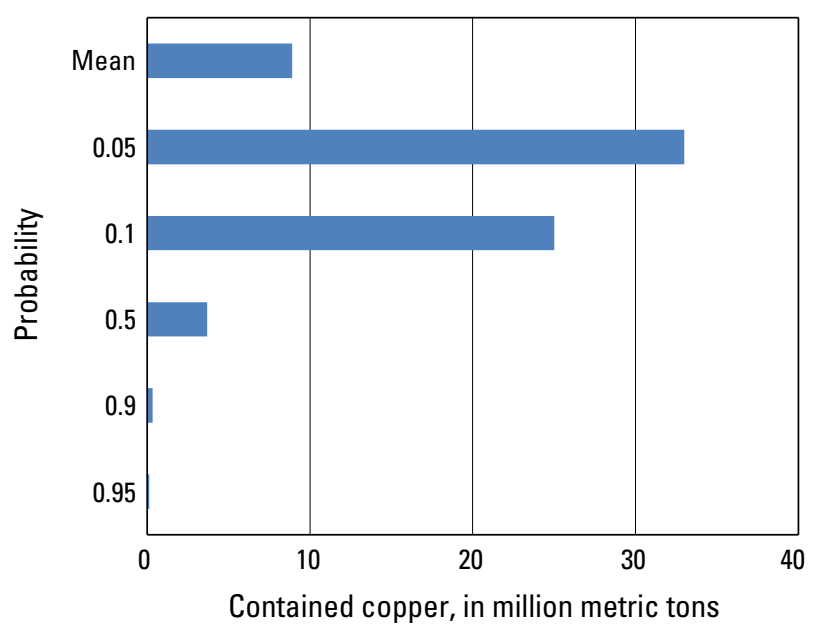

Figure 13. Histogram showing the results of a Monte Carlo computer simulation of undiscovered sandstone copper resources in tract 142ssCu8050 (TZ-1), Teniz Basin, Kazakhstan. 
Table 6. Results of Monte Carlo simulations of undiscovered resources in sandstone copper deposits in tract 142ssCu8050 (TZ-1), Teniz Basin, Kazakhstan.

[t, metric tons; Mt, million metric tons]

\begin{tabular}{|c|c|c|c|c|c|c|c|c|}
\hline \multirow[b]{2}{*}{ Material } & \multicolumn{5}{|c|}{ Probability of at least the indicated amount } & \multicolumn{3}{|c|}{ Probability of } \\
\hline & 0.95 & 0.9 & 0.5 & 0.1 & 0.05 & Mean & $\begin{array}{c}\text { Mean or } \\
\text { greater }\end{array}$ & None \\
\hline $\mathrm{Cu}(\mathrm{t})$ & 130,000 & 330,000 & $3,700,000$ & $25,000,000$ & $33,000,000$ & $8,900,000$ & 0.31 & 0.03 \\
\hline $\operatorname{Ag}(t)$ & 0 & 0 & 2,300 & 20,000 & 33,000 & 7,500 & 0.27 & 0.19 \\
\hline Rock (Mt) & 10 & 29 & 320 & 2,200 & 2,800 & 780 & 0.34 & 0.03 \\
\hline
\end{tabular}

Previous prognostic resource estimates $\left(\mathrm{P}_{1}+\mathrm{P}_{2}\right)$ for the Teniz copper ore cluster proposed 500,000 metric tons of copper (Information and Analysis Center of Geology and Mineral Resources of the Republic of Kazakhstan, 2008). This agency follows the resource and reserve classification system used in the former Soviet Union and other COMECON countries, in which prognostic resources are divided into two categories, $\mathrm{P}_{1}$ and $\mathrm{P}_{2}$ (Diatchkov, 1994; Jakubiak and Smakowski, 1994; Henley and Young, 2009). Prognostic resources are inferred from indirect indications of mineralization (such as geochemical or geophysical anomalies), mineral occurrences, or isolated sampling and are equivalent to undiscovered resources in the classification of mineral resources used by the USGS (U.S. Bureau of Mines and U.S. Geological Survey, 1976). Resources under the $P_{1}$ category may be adjacent to and extend beyond the limits of drill-indicated resources and can be considered more certain. Resources under the $\mathrm{P}_{2}$ category represent possible mineral structures in known mineral deposit or ore-bearing regions and are more conjectural than those in the $\mathrm{P}_{1}$ category (Diatchkov, 1994). Our estimate of contained copper at the 90th percentile, 330,000 metric tons, is similar to the $\left(\mathrm{P}_{1}+\mathrm{P}_{2}\right)$ prognostic resource estimate for the same region as calculated by the Government of Kazakhstan.

The small resource estimate for the Teniz Basin was influenced by several factors. Firstly, development of the giant Dzhezkazgan sandstone copper deposit, and exploration for nearby deposits in the Chu-Sarysu Basin, may have impeded exploration in the Teniz Basin. Additionally, concepts of ore genesis may have restrained exploration interest in this area. The syngenetic model was invoked in early papers on mineralization in the basin and genetic concepts emphasizing the hydrothermal nature of sedimenthosted stratabound copper deposits have been accepted since the initial exploration of that area was conducted. Recent seismic surveys show many potential structural traps that could localize sandstone subtype copper deposits that were not considered targets when exploration was conducted in the 1950s. Furthermore, the far-eastern half of the basin is buried under an undetermined thickness of unconsolidated Neogene and Quaternary sedimentary cover, adding significantly to the difficulties of minerals exploration.
With the available information, it is difficult to rigorously classify known prospects as sandstone subtype or red bed-type occurrences. Descriptive information is available for only 6 of the 100 or more mineral occurrences, and the extent and results of exploration activities conducted in the middle part of the last century are virtually unknown. Future assessments of the prospectivity of this region will be significantly enhanced if this information is found. Ideally, assessments are repeated on a recurring basis, at a variety of scales, because available data change over time and different datasets can affect assessment results.

\section{Acknowledgments}

USGS colleagues Stephen Box, George Breit, Susan Hall, and Jane Hammarstrom, served as the Assessment Oversight Committee to review the preliminary assessment results. Heather Parks, Kassandra Lindsey, and Michael Landkammer helped prepare the illustrations in this report. George Breit, and Susan Hall provided helpful and timely technical reviews of the final report. Series edit by Kathleen M. Johnson.

\section{References Cited}

Alexeiev, D.V., Cook, H.E., Buvtyshkin, V.M., and Golub, L.Y., 2009, Structural evolution of the Ural-Tian Shan junction: A view from Karatau ridge, South Kazakhstan: C.R. Geoscience, v. 341, p. 287-297.

Allen, M.B., Alsop, G.I., and Zhemchuzhnikov, V.G., 2001, Dome and basin refolding and transpressive inversion along the Karatau Fault System, southern Kazakhstan: Journal of the Geological Society of London, v. 158, p. 83-85.

Babi'chev, E.A., Igonina, S.A., Malinovska, S.P., and Malinovskiy, V.U., 1970a, Geologic map of USSR, UlutauKokchetav Series, sheet M-42-III: Ministry of Geology of the USSR (VSEGEI), scale 1:200,000. [In Russian.] 
Babi'chev, E.A., Igonina, S.A., Malinovska, S.P., and Malinovskiy, V.U., 1970b, Map of mineral resources of USSR, Ulutau-Kokchetav Series, sheet M-42-III: Ministry of Geology of the USSR (VSEGEI), scale 1:200,000. [In Russian.]

Bartholomé, Paul, ed., 1964, Gisements stratiformes et provinces cuprifères: Liège, Belgium, Société Géologique de Belgique, $427 \mathrm{p}$.

Bawiec, W.J., and Spanski, G.T., 2012, Quick-start guide for version 3.0 of EMINERS-Economic Mineral Resource Simulator: U.S. Geological Survey Open-File Report 2009-1057, 26 p., accessed July 15, 2012, at http://pubs. usgs.gov/of/2009/1057. (This report supplements USGS OFR 2004-1344.)

Bekker, A., Holland, H.D., Wang, P.-L., Rumble III, D., Stein, H.J., Hannah, J.L., Coetzee, L.L., and Beukes, N.J., 2004, Dating the rise of atmospheric oxygen: Nature, v. 427, p. 117-120.

Blackbourn, G.A., and Thomson, M.E., 2010, Middle Devonian to Carboniferous ocean-margin and carbonateplatform development across the East Turan Platform, West Kazakhstan Plateau and Western Tien Shan [abs.]: AAPG European Region Annual Conference abstracts, October 17-19, 2010 Kiev, Ukraine, accessed September 10, 2012, at http://www.searchanddiscovery. com/abstracts/pdf/2010/kiev/abstracts/ndx_Blackbourn.pdf.

Bogdanov, A.A., 1960, Basic features of the Paleozoic structure of Kazakhstan: International Geology Review, v. 2, no. 9, p. 781-810.

Bogdanov, Yu.V., and Feoktistov, V.P., 1972, Copper potential of Tengiz-Sarysu structural formation zone, Kazakhstan: International Geology Review, v. 14, no. 3, p. 254-265.

Bogdanov, Yu.V., Bur'yanova, E.Z., Kutyrev, E.I., Feoktistov, V.P., and Trifonov, N.P., 1973, Stratifitzirovannye mestorozhdeniya medi SSSR [Stratabound copper deposits of the USSR]: Leningrad, Nedra Publishing House, 312 p.

Box, S.E., Syusyura, B., Hayes, T.S., Taylor, C.D., Zientek, M.L., Hitzman, M.W., Seltmann, R., Chechetkin, V., Dolgopolova, A., Cossette, P.M., and Wallis, J.C., 2012, Sandstone copper assessment of the Chu-Sarysu Basin, Kazakhstan: U.S. Geological Survey Scientific Investigations Report 2010-5090-E, 63 p.

Briskey, J.A., Schulz, K.J., Mosesso, J.P., Horwitz, L.R., and Cunningham, C.G., 2001, It's time to know the planet's mineral resources: Geotimes, v. 46, no. 3, p. 14-19. (Also available at http://www.geotimes.org/mar01/.)

Canfield, D.E., 2005, The early history of atmospheric oxygen-Homage to Robert M. Garrels: Annual Reviews of Earth and Planetary Science, v. 33, p. 1-36.
Chandler, F.W., 1988, Diagenesis of sabkha-related, sulphate nodules in the Early Proterozoic Gordon Lake Formation, Ontario, Canada: Carbonates and Evaporites v. 3, no. 1 p. 75-94.

Committee for Mineral Reserves International Reporting Standards, 2006, International reporting template for the public reporting of exploration results, mineral resources and mineral reserves: accessed June 5, 2007, at http://www. crirsco.com/crirsco_template_v2.pdf.

Cox, D.P., Lindsey, D.A., Singer, D.A., and Diggles, M.F., 2003, Sediment-hosted copper deposits of the worldDeposit models and database (ver. 1.3, June, 2007): U.S. Geological Survey Open-File Report 2003-107 version 1.3, 50 p. (Also available at http://pubs.usgs.gov/of/2003/of03107/.)

Davidson, C.F., 1965, A possible mode of origin of stratabound copper ores: Economic Geology, v. 60, no. 5, p. 942-954.

Diatchkov, S.A., 1994, Principles of classification of reserves and resources in the CIS countries: Mining Engineering, v. 46, no. 3, p. 214-217.

Duval, J.S., 2012, Version 3.0 of EMINERS—Economic Mineral Resource Simulator: U.S. Geological Survey OpenFile Report 2004-1344, accessed July 15, 2012, at http:// pubs.usgs.gov/of/2004/1344.

Filippova. I.B., Bush, V.A., and Didenko, A.N., 2001, Middle Paleozoic subduction belts-The leading factor in the formation of the Central Asian fold-and-thrust belt: Russian Journal of Earth Sciences, v. 3, no. 6, p. 405-426.

Fugro Robertson, Ltd., 2008, Fugro Tellus sedimentary basins of the world map: AAPG Datapages, accessed November 6, 2009, at http://gisudril.aapg.org/gisdemo/FugroTellus.html.

Garlick, W.G., 1961, Ore genesis-The syngenetic theory, in Mendelson, F., ed., The geology of the Northern Rhodesian copperbelt: London, MacDonald, p. 146-165.

Hayes, T.S., Landis, G.P, Whelan, J.F., Rye, R.O., and Moscati, R.J., 2012, The Spar Lake stratabound Cu-Ag deposit formed across a mixing zone between trapped natural gas and metal-bearing brine: Economic Geology, v. 107, p. 1223-1250.

Henley, Stephen, and Young, Niall, 2009, Alignment of resource and reserve classification systems, Russian Federation and CRIRSCO: accessed February 22, 2011, at http://www.eurogeologists.de/images/content/dublin workshop_09/Alignment\%20of\%20CRIRSCO\%20and\%20 RF\%20systems\%20(N.\%20Young\%20et\%20al).ppt. 
Hitzman, M.W., Selley, David, and Bull, Stuart, 2010, Formation of sedimentary rock-hosted stratiform copper deposits through Earth history: Economic Geology, v. 105, no. 3, p. 627-639.

Hitzman, Murray, Kirkham, Rodney, Broughton, David, Thorson, Jon, and Selley, David, 2005, The sedimenthosted stratiform copper ore system, in Hedenquist, J.W., Thompson, J.F.H., Goldfarb, R.J., and Richards, J.P., eds., Economic Geology One Hundredth Anniversary Volume: 1905-2005: Littleton, Colorado, Society of Economic Geologists, p. 609-642.

Information and Analysis Center of Geology and Mineral Resources of the Republic of Kazakhstan, 2008, Republic of Kazakhstan map of licensed objects and areas disposal ore minerals - 01.08.08: [Kazakhstan] Ministry of Energy and Mineral Resource, Committee of Geology and Subsoil Usage, scale 1:2,500,000. (Also available at http://www. infocenter.kz/.)

Jakubiak, Z., and Smakowski, T., 1994, Classification of mineral reserves in the former Comecon countries, in Whateley, M.K., and Harvey, P.K., eds., Mineral resource evaluation II-Methods and case histories: Geological Society Special Publication 79, p. 17-28.

Jowett, E.C., 1991, The evolution of ideas about the genesis of stratiform copper-silver deposits, in Hutchenson, R.W., and Grauch, R.I., eds., Historical Perspectives of Genetic Concepts and Case Histories of Famous Discoveries: Economic Geology Monograph 8, Society of Economic Geologists, p. 117-132.

Kirkham, R.V., 1989, Distribution, settings, and genesis of sediment-hosted stratiform copper deposits: Geological Association of Canada Special Paper 36, p. 3-38.

Kirkham, R.V., Carriere, A.R., and Born, P., comps., 2008, World mineral deposit databases: Geological Survey of Canada, accessed December 20, 2010, at http://apps1.gdr. nrcan.gc.ca/gsc_minerals//.

Kirkham, R.V., Carriere, J.J., Larame, R.M., and Garson, D.F., 1994, Global distribution of sediment-hosted stratiform copper deposits and occurrences: Geological Survey of Canada Open File 2915b, 256 p.

Kushev, G.L., 1963, Karagandinskii uglenosnyi bassein (2d ed.): Alma-Ata, accessed September 19, 2012, at http://encyclopedia2.thefreedictionary.com/ Karaganda+Coal+Basin .

Lehmann, J.G., 1756, Versuch einer Geschichte von Flötzgebürgen: Berlin, F.A. Lange, p. 163-175.
Lindsey, D.A., and Cox, D.P., 2003, Descriptive model of Redbed Cu 30b.3 (ver. 1.3, June, 2007) in Cox, D.P., Lindsey, D.A., Singer, D.A., Moring, B.C., and Diggles, M.F., Sediment-hosted copper deposits of the worldDeposit models and database: U.S. Geological Survey Open-File Report 2003-107, 5 p. (Also available at http:// pubs.usgs.gov/of/2003/of03-107/.)

Magoon, L.B. and Dow, W.G., 1994, The petroleum system, in Magoon, L.B. and Dow, W.G., eds., The petroleum system-From source to trap: American Association of Petroleum Geologists Memoir 60, p. 3-24.

Magoon, L.B., and Schmoker, J.W., 2000, The total petroleum system-The natural fluid network that constrains the assessment unit, in USGS World Energy Assessment Team, U.S. Geological Survey World Petroleum Assessment 2000—Description and results: U.S. Geological Survey Digital Data Series 60, Chapter PS, 31 p.

Marochkin, N.N., Belyaev, A.A., and Prodanovich, M.I., 1994, Geological map of the Russian Federation, new series, sheet M-(41),42 Tselinograd (Akmola), Map of Mineral Resources: Committee of the Russian Federation on Geology and Mineral Resources, VSEGEI, scale 1,000,000. [In Russian.]

Mazarovich, O.A., comp., 1958a, Geologic map of USSR, Ulutau-Kokchetav Series, sheet M-42-XV: Ministry of Geology \& Mineral Resource Protection of the USSR (VSEGEI), scale 1:200,000. [In Russian.]

Mazarovich, O.A., comp., 1958b, Map of mineral resources of USSR, Ulutau-Kokchetav Series, sheet M-42-XV: Ministry of Geology \& Mineral Resource Protection of the USSR (VSEGEI), scale 1:200,000. [In Russian.]

Mikhailov, A.E., 1951, Map of mineral resources of USSR, Ulutau-Kokchetav Series, sheet M-42-VIII: Ministry of Geology \& Mineral Resource Protection of the USSR (VSEGEI), scale 1:200,000. [In Russian.]

Mikhailov, A.E., 1963, Map of mineral resources of USSR, Ulutau-Kokchetav Series, sheet M-42-II: Ministry of Geology \& Mineral Resource Protection of the USSR (VSEGEI), scale 1:200,000. [In Russian.]

Mikhailov, A.E., and Litvinovich, N.V., 1963, Geologic map of USSR, Ulutau-Kokchetav Series, sheet M-42-II: Ministry of Geology \& Mineral Resource Protection of the USSR (VSEGEI), scale 1:200,000. [In Russian.]

Minervin, O.V., comp., 1961a, Geologic map of USSR, Ulutau-Kokchetav Series, sheet M-42-XIV: Ministry of Geology \& Mineral Resource Protection of the USSR (VSEGEI), scale 1:200,000. [In Russian.] 
Minervin, O.V., comp., 1961b, Map of mineral resources of USSR, Ulutau-Kokchetav Series, sheet M-42-XIV: Ministry of Geology \& Mineral Resource Protection of the USSR (VSEGEI), scale 1:200,000. [In Russian.]

Oil \& Gas Journal, 1992, Kazakhstan unveils first round bid: Oil \& Gas Journal, accessed September 11, 2012, at http:// www.ogj.com/content/ogj/en/articles/print/volume-90/ issue-51/in-thisissue/exploration/kazakhstan-unveils-firstbid-round.html.

Oil \& Gas Journal, 1995, Kazakhstan receiving acreage applications: Oil \& Gas Journal, accessed September 11, 2012, at http://www.ogj.com/articles/print/volume-93/ issue-2/in-this-issue/exploration/kazakhstan-receivingacreage-applications.html.

Popov, V.M., 1962, Geologic regularities in the distribution of cupriferous sandstones in Kazakhstan and the Northern Tyan-Shan: International Geology Review, v. 4, p. 393-411.

Rentzsch, J., 1965, Fazielle Gesetzmässigkeiten beim Auftreten der Roten Fäule: Freiberger Forschungshhefte, C193, p. 99-106.

Root, D.H., Menzie, W.D., and Scott, W.A., 1992, Computer Monte Carlo simulation in quantitative resource estimation: Natural Resources Research, v. 1, no. 2, p. 125-138.

Root, D.H., Scott Jr., W.A., and Selner, G.I., 1996, Computer program for aggregation of probabilistic assessments of mineral resources: U.S. Geological Survey Open-File Report 96-094.

Rose, A.W., 1976, The effect of cuprous chloride complexes in the origin of red bed copper and related deposits: Economic Geology, v. 71, p. 1036-1048.

Rundkvist, D.V., ed., 2001, Mineragenetic map of Russian Federation and adjacent states (within the boundaries of former USSR): Ministry of Natural Resources of Russian Federation, State Research and Development Enterprise (Aerogeologica), 1 map on 18 sheets, scale 1:2,500,000, CD-ROM.

Rydzewski, A., 1969, Petrography of the copper-bearing Zechstein shales in the Fore-Sudetic monocline (Lower Silesia): Biuletyn Instytut Geologicznego, v. 217, p. 113167. [In Polish.]

Scheiderhölm, H., 1932, The geology of the copper belt, Northern Rhodesia: Mining Magazine, v. 46, p. 241-245.

Seltmann, R., Shatov, V., and Yakubchuk, A., eds., 2009, Mineral deposits database and thematic maps of Central Asia, scale 1.5 million: ArcGIS 9.2, ArcView 3.2 and MapInfo 6.0 (7.0) GIS Packages: London, Natural History Museum, Department of Mineralogy, Center for Russian and Central EurAsia Mineral Studies, 135 p., scale $1: 1,500,000$.
Seyfullin, S.S., Kalinin, S.K., Strutinskiyi, A.V., and Fayn, E.Ye, 1974, Rhenium in stratified copper deposits and showings in west Kazakhstan: Geochemistry International, v. 11, no. 2, p. 414-418.

Sinclair, A.J., and Blackwell, G.H., 2002, Applied mineral resource estimation: Cambridge, Cambridge University Press, $381 \mathrm{p}$.

Singer, D.A., 1993, Basic concepts in three-part quantitative assessments of undiscovered mineral resources: Nonrenewable Resources, v. 2, no. 2, p. 69-81.

Singer, D.A., 1995, World-class base and precious metal deposits-A quantitative analysis: Economic Geology, v. 90, no. 1, p. 88-104.

Singer, D.A., and Menzie, W.D., 2005, Statistical guides to estimating the number of undiscovered mineral depositsAn example with porphyry copper deposits, in Cheng, Qiuming and Bonham-Carter, Graeme, eds., Proceedings of IAMG-The annual conference of the International Association for Mathematical Geology: Geomatics Research Laboratory, York University, Toronto, Canada, p. 1028-1033.

Singer, D.A., and Menzie, W.D., 2010, Quantitative mineral resource assessments-An integrated approach: New York, Oxford University Press, 219 p.

Smirnov, Aleksander, 2008, Geology, geodynamics and ore fields of the Kazakhstan Paleocontinent's Main Suture Zone (MSZ) [abs.]: 33rd International Geologic Congress, Oslo, accessed Jan. 22, 2012, at http://www.cprm.gov. br/33IGC/1287174.html.

Sohn, I.G., 1987, The ubiquitous ostracode Darwinula stevensoni (Brady and Robertson, 1870), redescription of the species and lectotype designation: Micropaleontology, v. 33, p. 150-163.

Syusyura, B.B., 2008, Copper-bearing sandstones of Kazakhstan [abs.]: 33rd International Geologic Congress, Oslo, accessed 2011, at http://www.cprm.gov. br/33IGC/1342858.html.

Syusyura, B., Box, S.E., and Wallis, J.C., 2010, Spatial databases of geological, geophysical, and mineral resource data relevant to sandstone-hosted copper deposits in Kazakhstan: U.S. Geological Survey Open-File Report 2010-1124, 4 p. and databases. (Also available at http:// pubs.usgs.gov/of/2010/1124/.) 
Taylor, C.D., Causey, J.D., Denning, P.D., Hammarstrom, J.M., Hayes, T.S., Horton, J.D., Kirschbaum, M.J., Parks, H.L., Wilson, A.B., Wintzer, N.E., and Zientek, M.L., 2013, Descriptive models, grade-tonnage relations, and databases for the assessment of sediment-hosted copper deposits-With emphasis on deposits in the Central African Copperbelt, Democratic Republic of the Congo and Zambia: U.S. Geological Survey Scientific Investigations Report 2010-5090-J, 154 p. and data files.

Taylor, D., 2000, Introduction-A ‘soft-rock’ petroleumtype approach to exploration for 'hard-rock' minerals in sedimentary basins, in Glikson, M., and Mastalerz, M., eds., Organic matter and mineralization: Dordrecht, The Netherlands, Kluwer Academic Publishers, p. 1-12.

U.S. Bureau of Mines and U.S. Geological Survey, 1976, Principles of a resource/reserve classification for minerals: U.S. Geological Survey Circular 831, 5 p.

U.S. Department of State, 2009, Small-scale digital international land boundaries (SSIB) — Lines, edition 10, and polygons, beta edition 1, in Boundaries and sovereignty encyclopedia (B.A.S.E.): U.S. Department of State, Office of the Geographer and Global Issues.

Vavic, E.A., and Rosen, O.M., 1963, Map of mineral resources of USSR, Ulutau-Kokchetav Series, sheet N-42-XXXIV: Ministry of Geology \& Mineral Resource Protection of the USSR (VSEGEI), scale 1:200,000. [In Russian.]

White, W.S., and Wright, J.C., 1954, The White Pine copper deposit, Ontonagon County, Michigan: Economic Geology, v. 49 , p. 675-716.

Wilhem, Caroline, Windley, B.F., and Stampfli, G.M., 2012, The Altaids of Central Asia-A tectonic and evolutionary innovative review: Earth-Science Reviews, v. 113, p. 303341.

Windley, B.F., Alexeiev, Dmitry, Xiao, Wenjiao, Kröner, Alfred, and Badarch, Gombosuren, 2007, Tectonic models for accretion of the central Asian Orogenic Belt: Journal of the Geological Society of London, v. 164, p. 31-47.
Wyborn, L.A.I., Heinrich, C.A, and Jaques, A.L., 1994. Australian Proterozoic mineral systems essential ingredients and mappable criteria: Proceedings of the Australasian Institute of Mining and Metallurgy Annual Conference, Darwin, Australia, p. 109-116, accessed May 24, 2012, at http://www.ga.gov.au/image_cache/GA5228.pdf.

Zharkov, M.A., 1988, Devonian evaporite basins (distribution, paleogeography): Canadian Society of Petroleum Geologists, Memoir 14, p. 415-425.

Zientek, M.L., and Hammarstrom, J.M., 2008, An overview of the USGS Global Mineral Resource Assessment project [abs.], in International Geological Congress Oslo 2008, August 6-14th, accessed November 1, 2012, at http://www. cprm.gov.br/33IGC/1320661.html.

Zientek, M.L., Hayes, T.S., and Hammarstrom, J.H., 2013, Overview of a new descriptive model for sediment-hosted stratabound copper deposits, in Taylor, C.D., Causey, J.D., Denning, P.D., Hammarstrom, J.M., Hayes, T.S., Horton, J.D., Kirschbaum, M.J., Parks, H.L., Wilson, A.B., Wintzer, N.E., and Zientek, M.L., Descriptive models, grade-tonnage relationships, and databases for the assessment of sedimenthosted copper deposits-With emphasis on deposits in the Central Africa Copperbelt, Democratic Republic of the Congo and Zambia: U.S. Geological Survey Scientific Investigations Report 2010-5090-J, p. 2-16. (Also available at http://pubs.usgs.gov/sir/2010/5090/j/.)

Zientek, M.L., Hayes, T.S., and Taylor, C.D., 2013, Grade and tonnage relations for sediment-hosted stratabound copper deposits, in Taylor, C.D., Causey, J.D., Denning, P.D., Hammarstrom, J.M., Hayes, T.S., Horton, J.D., Kirschbaum, M.J., Parks, H.L., Wilson, A.B., Wintzer, N.E., and Zientek, M.L., Descriptive models, grade-tonnage relationships, and databases for the assessment of sediment-hosted copper deposits-With emphasis on deposits in the Central Africa Copperbelt, Democratic Republic of the Congo and Zambia: U.S. Geological Survey Scientific Investigations Report 2010-5090-J, p. 17-59. (Also available at http://pubs.usgs. gov/sir/2010/5090/j/.) 
Appendixes A-E 


\section{Appendix A. Principal Sources of Information Used by the Assessment Team}

Table A1. List of principal sources used to compile database.

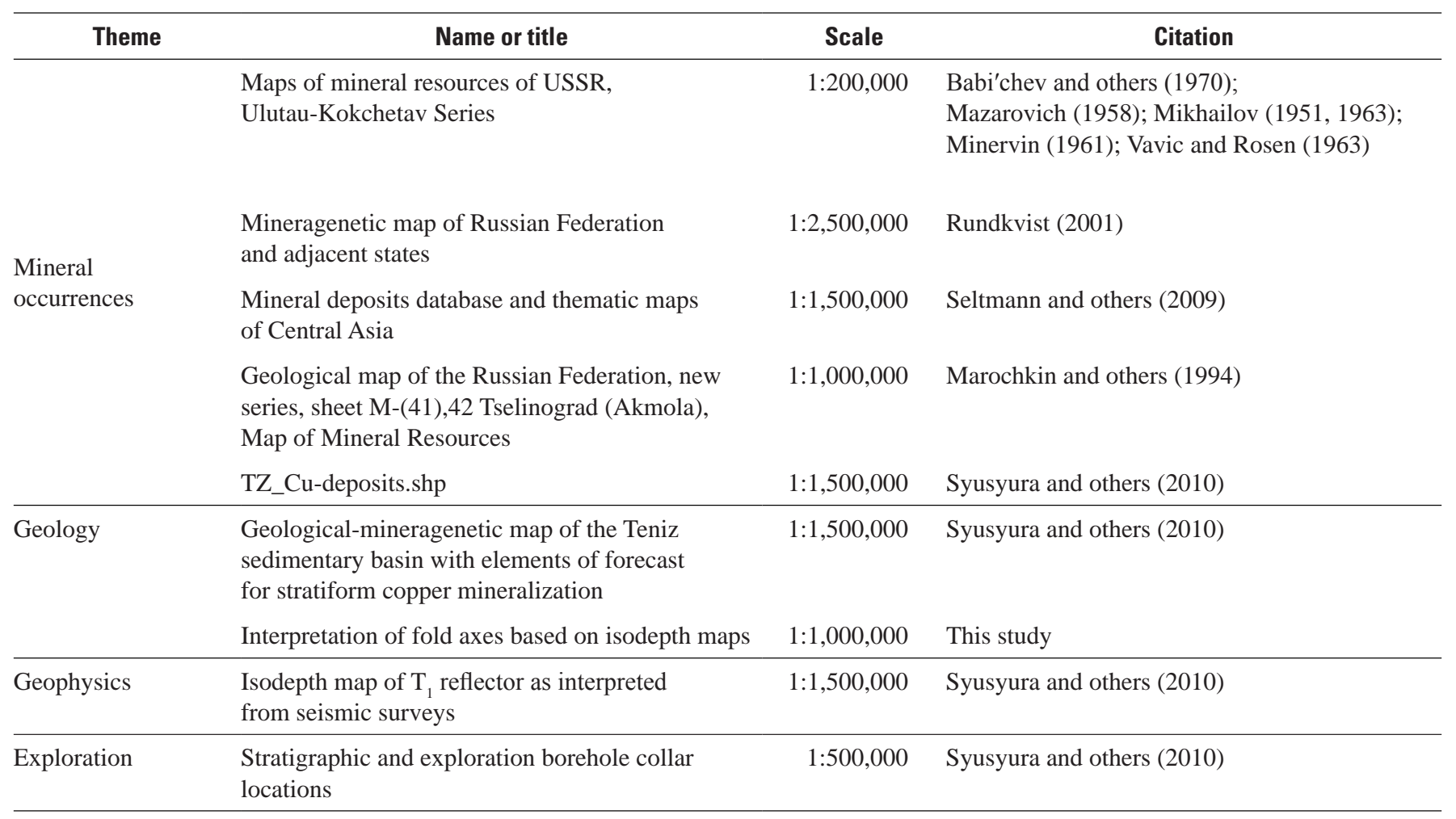




\section{References Cited}

Babi'chev, E.A., Igonina, S.A., Malinovska, S.P., and Malinovskiy, V.U., 1970, Map of mineral resources of USSR, Ulutau-Kokchetav Series, sheet M-42-III: Ministry of Geology of the USSR (VSEGEI), scale 1:200,000. [In Russian.]

Marochkin, N.N., Belyaev, A.A., and Prodanovich, M.I., 1994, [Geological map of the Russian Federation, new series, sheet M-(41),42 Tselinograd (Akmola), Map of Mineral Resources]: Committee of the Russian Federation on Geology and Mineral Resources, VSEGEI, scale 1,000,000. [In Russian.]

Mazarovich, O.A., comp., 1958, Map of mineral resources of USSR, Ulutau-Kokchetav Series, sheet M-42-XV: Ministry of Geology \& Mineral Resource Protection of the USSR (VSEGEI), scale 1:200,000. [In Russian.]

Mikhailov, A.E., 1951, Map of mineral resources of USSR, Ulutau-Kokchetav Series, sheet M-42-VIII: Ministry of Geology \& Mineral Resource Protection of the USSR (VSEGEI), scale 1:200,000. [In Russian.]

Mikhailov, A.E., 1963, Map of mineral resources of USSR, Ulutau-Kokchetav Series, sheet M-42-II: Ministry of Geology \& Mineral Resource Protection of the USSR (VSEGEI), scale 1:200,000. [In Russian.]
Minervin, O.V., comp., 1961, Map of mineral resources of USSR, Ulutau-Kokchetav Series, sheet M-42-XIV: Ministry of Geology \& Mineral Resource Protection of the USSR (VSEGEI), scale 1:200,000. [In Russian.]

Rundkvist, D.V., ed., 2001, Mineragenetic map of Russian Federation and adjacent states (within the boundaries of former USSR): Ministry of Natural Resources of Russian Federation, State Research and Development Enterprise (Aerogeologica), 1 map on 18 sheets, scale 1:2,500,000, CD-ROM.

Seltmann, R., Shatov, V., and Yakubchuk, A., eds., 2009, Mineral deposits database and thematic maps of Central Asia, scale 1.5 million: ArcGIS 9.2, ArcView 3.2 and MapInfo 6.0(7.0) GIS Packages: Center for Russian and Central EurAsia Mineral Studies, Department of Mineralogy, Natural History Museum, London, UK, 135 p., scale $1: 1,500,000$.

Syusyura, Boris, Box, S.E., and Wallis, J.C., 2010, Spatial databases of geological, geophysical, and mineral resource data relevant to sandstone-hosted copper deposits in Kazakhstan: U.S. Geological Survey Open-File Report 2010-1124, 4 p. and databases. (Also available at http:// pubs.usgs.gov/of/2010/1124/.)

Vavic, E.A., and Rosen, O.M., 1963, Map of mineral resources of USSR, Ulutau-Kokchetav Series, sheet N-42-XXXIV: Ministry of Geology \& Mineral Resource Protection of the USSR (VSEGEI), scale 1:200,000. [In Russian.] 


\section{Appendix B. Grade and Tonnage Model for Sandstone Copper Deposits}

\section{Description}

The grade and tonnage model used for this assessment is based on 70 known sandstone copper deposits (table B1) and resource estimates that were available through the end of 2011. Sites with estimated resources of less than 10,000 metric tons of contained copper are not included in the model because they may not be fully explored or of economic interest in current market conditions.

Spatial aggregation rules are applied to ensure that deposits in grade and tonnage and spatial density models correspond to deposits as geologic entities. These rules are essential to complete an assessment in which the estimated number of undiscovered deposits is consistent with the grade and tonnage model (Singer and Menzie, 2010). For this dataset, a 500-m aggregation rule was used by measuring either from the edge of a deposit polygon or between points representing deposit locations. Aggregated deposits are labeled “*” in the Site column in table B1.
For all sandstone copper deposits identified worldwide, the mean and median values for ore tonnage are 77 and 10 million metric tons, respectively. Mean and median copper grades are 1.4 and 1.2 percent copper (table A2). Distributions of ore tonnage, copper grade, and contained copper are all positively skewed and consistent with a normal model. Cobalt and silver data are missing for 96 and 73 percent of the samples, respectively. Log-transformed values of copper and cobalt grades do not show significant correlation with log-transformed values of tonnage. The grade and tonnage distributions are illustrated as cumulative frequency plots in figure 9 .

\section{Reference Cited}

Singer, D.A., and Menzie, W.D., 2010, Quantitative mineral resource assessments-An integrated approach: New York, Oxford University Press, 219 p.

Table B1. Deposit data used to develop grade and tonnage model for sandstone copper deposits.

[t, metric tons; \%, percent; g/t, grams per metric ton; *, site includes multiple deposits, aggregated using the 500-m spatial separation rule; DRC, Democratic Republic of the Congo; -, no data]

\begin{tabular}{|c|c|c|c|c|c|}
\hline Deposit name & Site & Country & $\begin{array}{c}\text { Ore } \\
(t)\end{array}$ & $\begin{array}{c}\text { Copper grade } \\
(\%)\end{array}$ & $\begin{array}{c}\text { Silver grade } \\
(\mathrm{g} / \mathrm{t})\end{array}$ \\
\hline Bwana Mkubwa & & Zambia & $8,600,000$ & 3.34 & - \\
\hline Cashin & & United States & $7,141,000$ & 0.53 & - \\
\hline Cattle Grid & & Australia & $7,200,000$ & 1.90 & 8.0 \\
\hline Centennial & & United States & $24,415,944$ & 0.59 & - \\
\hline Chejiang & & China & $3,022,321$ & 1.12 & - \\
\hline Chibuluma South & & Zambia & $7,365,766$ & 3.70 & - \\
\hline Chibuluma_Chibuluma West & $*$ & Zambia & $19,922,000$ & 3.69 & - \\
\hline Chifupu & & Zambia & $1,936,000$ & 3.05 & - \\
\hline Christiadore & & Namibia & $1,200,000$ & 2.30 & - \\
\hline Copper Gulch & & United States & $13,608,000$ & 0.53 & 51.4 \\
\hline Dacun & & China & $12,777,778$ & 1.80 & - \\
\hline Datongchang & & China & $14,810,833$ & 1.20 & - \\
\hline Dzhezkazgan & & Kazakhstan & $2,000,000,000$ & 1.10 & - \\
\hline East Sary Oba & & Kazakhstan & $91,400,000$ & 0.85 & - \\
\hline Fitula & & Zambia & $4,500,000$ & 5.00 & - \\
\hline Geyiza & & China & $3,120,000$ & 1.00 & - \\
\hline GTO & & United States & $4,463,000$ & 0.84 & - \\
\hline Haojiahe & & China & $14,101,852$ & 1.08 & - \\
\hline Horizon Basin & & United States & $10,069,920$ & 0.60 & 61.7 \\
\hline Itauz & & Kazakhstan & $94,140,000$ & 0.92 & - \\
\hline Itawa & & Zambia & $40,000,000$ & 0.76 & - \\
\hline $\mathrm{JF}$ & & United States & $13,600,000$ & 0.40 & 44.6 \\
\hline
\end{tabular}


Table B1. Deposit data used to develop grade and tonnage model for sandstone copper deposits. - Continued

[t, metric tons; \%, percent; g/t, grams per metric ton; *, site includes multiple deposits, aggregated using the 500-m spatial separation rule; DRC, Democratic Republic of the Congo; -, no data]

\begin{tabular}{|c|c|c|c|c|c|}
\hline Deposit name & Site & Country & $\begin{array}{c}\text { Ore } \\
(t)\end{array}$ & $\begin{array}{c}\text { Copper grade } \\
(\%)\end{array}$ & $\begin{array}{c}\text { Silver grade } \\
(\mathrm{g} / \mathrm{t})\end{array}$ \\
\hline Jiuquwan & & China & $10,076,923$ & 1.17 & - \\
\hline Juramento & & Argentina & $44,700,000$ & 0.80 & 21.8 \\
\hline Karshoshak & & Kazakhstan & $8,900,000$ & 1.46 & - \\
\hline Kasaria_Luansobe & & Zambia & $21,500,000$ & 2.31 & - \\
\hline Kinsenda & & DRC & $35,000,000$ & 5.50 & - \\
\hline Kipshakpai & & Kazakhstan & $38,500,000$ & 0.94 & - \\
\hline Laoqingshan & & China & $1,377,049$ & 1.22 & - \\
\hline Liuju & & China & $30,860,000$ & 1.32 & - \\
\hline Lubembe & & DRC & $47,500,000$ & 2.20 & - \\
\hline Malachite Pan & & Namibia & $3,000,000$ & 2.10 & - \\
\hline Mangula & & Zimbabwe & $62,000,000$ & 1.20 & 12.0 \\
\hline Mimbula & $*$ & Zambia & $46,850,000$ & 1.20 & - \\
\hline Missoula National & & United States & $4,500,000$ & 0.50 & 34.0 \\
\hline Mokambo North & & Zambia & $3,854,000$ & 1.70 & - \\
\hline Mokambo Project-Mokambo South & $*$ & Zambia & $20,900,000$ & 1.64 & - \\
\hline Moudin & & China & $14,414,063$ & 1.28 & - \\
\hline Mufulira & & Zambia & $332,586,652$ & 2.66 & - \\
\hline Mutundu North & & Zambia & $4,300,000$ & 1.44 & - \\
\hline Mwambashi B & & Zambia & $14,210,000$ & 1.78 & - \\
\hline Mwerkera & & Zambia & $7,100,000$ & 1.53 & - \\
\hline Ndola East & & Zambia & $40,000,000$ & 0.76 & - \\
\hline Niagara & & United States & $17,000,000$ & 0.47 & 16.0 \\
\hline Norah & & Zimbabwe & $10,000,000$ & 1.20 & - \\
\hline Nsato & & Zambia & $8,400,000$ & 1.61 & - \\
\hline Oamites & & Namibia & $6,100,000$ & 1.33 & 12.3 \\
\hline Okasewa & & Namibia & $6,000,000$ & 1.80 & - \\
\hline Pitanda South & & Zambia & $7,060,000$ & 1.58 & - \\
\hline Qingshuihe & & China & 969,136 & 1.62 & - \\
\hline Repparfjord & & Norway & $10,000,000$ & 0.72 & 70.0 \\
\hline Rock Creek/Montanore & & United States & $299,000,000$ & 0.81 & 71.0 \\
\hline Rock Peak & & United States & $9,888,480$ & 0.65 & 92.6 \\
\hline Sauzal Bonito & & Argentina & $2,000,000$ & 0.50 & - \\
\hline Sebembere & & Zambia & $5,700,000$ & 1.70 & - \\
\hline Sentinel & & United States & $4,465,000$ & 0.40 & - \\
\hline Shackleton & & Zimbabwe & $3,400,000$ & 1.20 & - \\
\hline Shimenkan & & China & $1,000,000$ & 1.09 & - \\
\hline Silverside & & Zimbabwe & 900,000 & 1.80 & - \\
\hline Spar Lake & & United States & $80,600,000$ & 0.63 & 46.0 \\
\hline Tordillos & & Argentina & $9,350,000$ & 0.42 & - \\
\hline Tschudi & & Namibia & $57,000,000$ & 0.72 & 11.0 \\
\hline Udokan & & Russia & $1,300,000,000$ & 1.45 & 13.0 \\
\hline Unkur & & Russia & $90,900,000$ & 0.75 & 70.8 \\
\hline Vermilion River & & United States & $13,600,000$ & 0.50 & 30.8 \\
\hline Wadi Abu Khushaybah & & Jordan & $8,000,000$ & 0.65 & - \\
\hline West Sary Oba & & Kazakhstan & $86,200,000$ & 0.89 & - \\
\hline Witvlei Pos & & Namibia & $2,800,000$ & 1.50 & - \\
\hline Zhaman-Aibat & & Kazakhstan & $193,000,000$ & 1.40 & 16.0 \\
\hline Zhangjiachunshengjiping & & China & $1,836,735$ & 0.98 & - \\
\hline
\end{tabular}


Table B2. Summary statistics for sandstone copper deposits.

[Mt, million metric tons; \%, percent; g/t, grams per metric ton; -, no data]

\begin{tabular}{|c|c|c|c|c|c|c|c|c|c|}
\hline & $\begin{array}{c}\text { Number of } \\
\text { deposits }\end{array}$ & Mean & \multicolumn{7}{|c|}{ Quartile } \\
\hline Ore (Mt) & 70 & 77 & 1.1 & 1.9 & 4.5 & 10 & 39 & 91 & 310 \\
\hline Silver grade (g/t) & 18 & 38 & 8.0 & 11 & 13 & 32 & 64 & 73 & 93 \\
\hline Cobalt grade (\%) & 3 & 0.1 & - & - & - & - & 0.2 & 0.2 & 0.2 \\
\hline
\end{tabular}




\section{Appendix C. Description of GIS Files and Data Package}

Digital data available with this report include GIS data described below and an Excel spreadsheet containing information presented in table 1.

GIS data are:

An Esri file geodatabase - a collection of various types of GIS datasets stored in a file system folder, TZ_ssC u_ Assessment.gdb.

Two feature datasets, Teniz_Basin_Tract_Equal_Area and Teniz_Basin_sedC $u_{-}$prospects, organize two feature classes representing spatial data results of this study. Teniz_Basin_Tract_Equal_Area contains the permissive tract (polygon) feature class, $\mathbf{T} \bar{Z}_{-} \mathbf{s s} \mathbf{C} \mathbf{u}_{-}$Tract, and Teniz_Basin_ sedC $u_{-}$prospects contains the prospects (points) feature class, TZ_ssC u_Prospects.

Two shapefiles, TZssC uTract.shp and TZssC uPros.shp, correspond to feature classes and are included for convenience in the zipped data package provided. Feature classes and corresponding shapefiles are as follows:

TZ_ssC u_Tract (T ZssC uTract.shp): Attributes include tract identifiers, tract name, a brief description of the basis for tract delineation, and assessment results. Attributes are briefly defined in the metadata accompanying these data.

TZ_ssC u_Prospects (TZssC uPros.shp): Attributes include the assigned tract, alternate site names, age, mineralogy, site status, comments fields, data sources and references. Attributes are briefly defined in the metadata accompanying these data.

The two feature classes (tract and prospects) are included in an Esri map document (ArcGIS Desktop 10 Service pack 3): TZ_GIS_SIR 5090-R . $\mathbf{m} \times \mathbf{d}$.

The complete data package may be downloaded from the USGS website as zipped file sir2010-5090R_gis.zip.

\section{Appendix D. Short Biographies for Members of the Assessment Team}

Arthur A. Bookstrom is a research geologist with the USGS in Spokane, Washington. He received his degrees in geology from Dartmouth College, the University of Colorado, and Stanford University. He is an economic geologist with expertise on porphyry-related deposits and mineral resource assessment.

Pamela M. C ossette is a biologist, geologist, geographer, and geographic information systems (GIS) specialist with the USGS in Spokane, Washington. She received her degree in geology from Eastern Washington University.

Timothy S. $\mathbf{H}$ ayes is a research geologist with the USGS in Tucson, Arizona. He received his degrees in geology from the South Dakota School of Mines and Stanford University. He is an economic geologist with expertise in sediment-hosted copper deposits.
Gilpin R . R obinson, J r., is a research geologist, geochemist, and mineral resources specialist with the USGS in Reston, Virginia, USA. He received his degrees in geology from Tufts University and Harvard University. He works on mineral resource assessment and other projects, including geologic mapping, studies of the origin and genesis of metal and industrial mineral deposits, and geochemical modeling.

J ohn C. Wallis is a geologist and geographic information systems (GIS) specialist with the USGS in Spokane, Washington, USA. He received his degree in geology from Eastern Washington University.

M ichael L . Zientek is a research geologist with the USGS in Spokane, Washington. He received his degrees in geology from the University of Texas and Stanford University. $\mathrm{He}$ is an economic geologist with expertise in magmatic ore deposits and mineral resource assessment. He is co-chief of the USGS Global Mineral Resource Assessment Project. 


\section{Appendix E. Assessment Terminology}

Terminology used in the Global Mineral Resource Assessment Project is adapted from definitions established for mineral resource assessments conducted by the U.S. Geological Survey using the 3-part form of mineral resource assessment (Singer, 1993), fundamental definitions for mineral deposit models (Cox and Singer, 1986), and definitions for a mineral resource classification established by the U.S. Bureau of Mine and U.S. Geological Survey (1976). Other definition sources for terms are noted.

Cost models Capital and operating cost equations that estimate the cost to develop a mineral deposit given its tonnage, grade, mining and milling methods, and depth. (Singer, written comm., 6/11/2007). Simplified cost models for mining and beneficiation (milling) can be used to calculate the proportion of resources contained in a deposit model that might be economically produced at stated conditions (D.W. Menzie, written commun., 2005).

C umulative past production Total amount of all past production (U.S. Geological Survey National Mineral Resource Assessment Team, 2000).

C umulative probability distributions for resource estimates Graphical depictions of estimated resource volumes presented with associated cumulative probabilities of occurrence. The distributions are used to derive the percent (95, 90, 50, 10, 5), and mean resource levels reported: a low case, with a 95 percent probability of that amount or more occurring (a 19 in 20 chance); a high case, with a 5 percent probability of that amount or more occurring (a 1 in 20 chance); and a mean case representing an arithmetic average of all possible outcomes weighted by their probabilities (U.S. Geological Survey National Oil and Gas Resource Assessment Team, 1995).

C utoff grade (a) Any grade that, for any specified reason, is used to separate two courses of action, for example, to mine or to leave, to mill or to dump; also, any of a series of grades used to truncate a frequency distribution, or to separate mineralized materials into graded fractions (Taylor, 1972).

(b) The lowest grade, or quality, of mineralized material that qualifies as economically mineable and available in a given deposit. May be defined on the basis of economic evaluation, or on physical or chemical attributes that define an acceptable product specification (Committee for Mineral Reserves International Reporting Standards, 2006). (Please be aware that a growing consortium of the minerals industry now uses the second, more restricted definition of this term).

Deposit density models Frequency distribution of number of deposits from the grade and tonnage model per unit of permissive control area. These models are commonly applied in a regression of number of deposits versus area permissive. These models are used to estimate the number of deposits or guide estimation. (D.A. Singer, written comm., 2007)
Descriptive mineral deposit model A set of data in a convenient form describing a group of mineral deposits having similar characteristics (U.S. Geological Survey National Mineral Resource Assessment Team, 2000). The model identifies the geologic environments in which the deposit type is a found and provides identifying characteristics of the type.

Discovered resources Total amount of identified resources and cumulative past production (U.S. Geological Survey National Mineral Resource Assessment Team, 2000).

G iant deposit A mineral deposit whose contained metal content ranks in the upper 10 percent of all known deposits. Accordingly, giant gold deposits contain at least $100 \mathrm{t}$ of gold, giant silver deposits contain more than 2,400 $\mathrm{t}(77 \mathrm{Moz}$ ) of silver, and giant copper, zinc, and lead deposits contain at least 2, 1.7, and $1 \mathrm{Mt}$ of their respective metals (Singer, 1995). Synonym: World-class deposit.

Grade and tonnage model Frequency distributions of pre-mining tonnages, and average grades of well-explored deposits of a given type, that are used to model grades and tonnages for undiscovered deposits of the same type, in geologically similar settings. Models are constructed on the basis of average grades of each commodity of possible economic interest and associated tonnage based on total production, reserves, and resources at the lowest possible cutoff grade (Singer and Berger, 2007). Mineral deposits in grade and tonnage models should be completely characterized in terms of location, tonnage, and grade.

Grade Average metal content measured as a percentage of weight of a given volume of mineralized rock. It is estimated by analyzing samples of the deposit. (D.W. Menzie, written commun., 2005).

Identified resources Resources whose location, grade, quality, and quantity are known or can be estimated from specific geologic evidence (U.S. Bureau of Mines and U.S. Geological Survey, 1976).

M etal endowment The sum of metal in all occurrences with specified characteristics, such as concentration, size, and depth (Harris, 1984).

M ineral deposit (a) A mineral occurrence of sufficient tonnage and grade that it might, under the most favorable of circumstances, be considered to have economic potential (Cox and Singer, 1986). (b) A mass of naturally occurring mineral materials, for example, metal ores or nonmetallic minerals, usually of economic value, without regard to mode of origin (Bates and Jackson, 1987). (c) An accumulation of associated mineralized bodies that constitute a single mineralizing event, including subsequent processes (for example, oxidation and supergene enrichment) affecting part or all of the accumulation (Barton and others, 1995). 
M ineral deposit type (a) Deposits sharing a relatively wide variety and large number of attributes (Cox and Singer, 1986). (b) A class representing all the recognized mineral deposits that are defined by physical and genetic factors that can be consistently differentiated from those of other classes or deposit types (Barton and others, 1995).

M ineral occurrence (a) A concentration of a mineral that is considered valuable by someone somewhere, or that is of scientific or technical interest (Cox and Singer, 1986). (b) Any ore or economic mineral in any concentration found in bedrock or as float; especially a valuable mineral in concentration sufficient to suggest further exploration (Bates and Jackson, 1987).

M ineral prospect (a) An area that is a potential site of mineral deposits, based on mineral exploration (Bates and Jackson, 1987). (b) Sometimes, an area that has been explored in a preliminary way but has not given evidence of economic value (Bates and Jackson, 1987). (c) An area to be searched by some investigative technique, for example, geophysical prospecting (Bates and Jackson, 1987). (d) A geologic or geophysical anomaly, especially one recommended for additional exploration (Bates and Jackson, 1987). (e) A mineral property whose value has not been proved by exploration (BLM, 1999).

M ineral reserve Mineral reserves are estimates of mineral as mined (allowing for losses and dilution) (Committee for Mineral Reserves International Reporting Standards, 2006).

M ineral resource (a) A concentration of naturally occurring mineral material in or on the Earth's crust in such form that economic extraction of a commodity from the concentration is currently or potentially feasible (Modified from U.S. Bureau of Mine and U.S. Geological Survey, 1976 by adding the word mineral). (b) A concentration or occurrence of material of economic interest in or on the Earth's crust in such form, quality and quantity that there are reasonable prospects for eventual economic extraction. The location, quantity, grade, continuity, and other geological characteristics of a mineral resource are known, estimated, or interpreted from specific geological evidence, sampling, and knowledge (Committee for Mineral Reserves International Reporting Standards, 2006). (Please be aware that a growing consortium of the minerals industry now uses the second, more restricted definition of this term).

M ineralization (a) Any single mineral or combination of minerals occurring in a mass, or deposit, of economic interest. The term is intended to cover all forms in which mineralization might occur, whether by class of deposit, mode of occurrence, genesis or composition (Committee for Mineral Reserves International Reporting Standards, 2006). (b) The process or processes by which a mineral or minerals are introduced into a rock, resulting in a valuable or potentially valuable deposit (Bates and Jackson, 1987).

M ineral-resource assessment A study that estimates or evaluates the amount and (or) potential supply of mineral resources within a specific volume of the Earth's crust.
Number of undiscovered mineral deposits estimates

The probability, or degree of belief, that a fixed but unknown number of deposits like those in the grade and tonnage model exist in the delineated tracts (D.W. Menzie, written commun., 2005).

Ore (a) A mineral assemblage of actual or potential economic interest (Taylor, 1972). (b) The naturally occurring material from which a mineral or minerals of interest can be extracted at a reasonable profit (Bates and Jackson, 1987).

O re deposit (a) A mineral deposit that has been tested and is known to be of sufficient size, grade, and accessibility to be producible to yield a profit (Cox and Singer, 1986). (b) A mineral deposit of high enough quality to mined at a profit (BLM, 1999).

Permissive tract A geographic area delineated such that the probability of deposits of the type delineated occurring outside the boundary is negligible (that is, less than 1 in 100,000 to $1,000,000$ ) (Singer, 1993). The delineated area represents the surface projection of a part of the Earth's crust and overlying surficial materials that corresponds to a geologic environment described in a published deposit model; consequently, depth from surface is an essential part of a tract definition. A permissive tract can be subdivided into two or more parts that have different kinds of information or possibly different numbers of undiscovered deposits.

\section{Q uantitative assessment of undiscovered resources}

A study that presents a numerical estimate of the amount and quality of undiscovered mineral resources present within a specific volume of the Earth's crust; because of the uncertainty inherent in assessment of unknown resource, the results are presented probabilistically.

R esource A concentration of naturally occurring solid, liquid, or gaseous material in or on the Earth's crust in such form that economic extraction of a commodity from the concentration is currently or potentially feasible (U.S. Bureau of Mines and U.S. Geological Survey, 1976).

Resource uncertainty Uncertainty means variability or being unknown; in mineral resource assessments it refers to possible locations of undiscovered resources and to the amounts and qualities of these resources. Location uncertainty is addressed by permissive tracts, and uncertainty of amounts and qualities is addressed by estimates of undiscovered deposits and grade and tonnage models (See Cunningham and others, 2008, for example).

Significant deposit A mineral deposit whose contained metal content ranks in the upper 99 percent of all known deposits. Accordingly, significant gold deposits contain at least $2 \mathrm{t}$ of gold, significant silver deposits contain more than $85 \mathrm{t}$ of silver, and significant copper, zinc, and lead deposits contain at least 50,000, 35,000, and 50,000 t of their respective metals (Long and others, 2000).

Spatial rule An operational spatial rule developed to ensure that deposits in grade and tonnage and spatial density models correspond to deposits as geologic entities (Singer and Menzie, 2010). 
Supergiant deposit A mineral deposit whose contained metal content ranks in the upper 1 percent of all known deposits. Accordingly, supergiant gold deposits contain at least 1,200 t of gold, supergiant silver deposits contain more than 22,000 t of silver, and supergiant copper, zinc, and lead deposits contain at least 24, 12, and $7 \mathrm{Mt}$ of their respective metals (Singer, 1995).

Tonnage Weight of a volume of mineralized rock (D.W. Menzie, written commun., 2005).

Undiscovered mineral deposit (a) A mineral deposit that may exist within a specified volume of Earth's crust (for example, $1 \mathrm{~km}$ or less from the surface of the ground). (b) An incompletely explored mineral occurrence or prospect that could have sufficient size and grade to be classified as a deposit. (c) A mineral deposit whose location and (or) grade, quality, and quantity of mineralized material are unknown or incompletely characterized.

Undiscovered resource (a) Resources in undiscovered mineral deposits whose existence is postulated on the basis of indirect geologic evidence (U.S. Geological Survey National Mineral Resource Assessment Team, 2000). (b) Mineralized material whose location, grade, quality, and quantity are unknown or incompletely characterized.

\section{References Cited}

Barton, P.B., Brew, D.A., Ludington, Steve, Lindsey, D.A., Ayuso, R.A., Force, E.R., Gamble, B.M., Goldfarb, R.J., John, D.A., and Johnson, K.M., 1995, Recommendations for assessments of undiscovered mineral resources: U.S. Geological Survey Open-File Report 95-82, 136 p.

Bates, R.L., and Jackson, J.A., eds., 1987, Glossary of geology, third edition: Alexandria, Virginia, American Geological Institute, 788 p.

BLM, 1999, 3829 Surface Management Regulations, Draft EIS, Glossary, accessed July 25, 2007, at http://www.blm. gov/nhp/Commercial/SolidMineral/3809/deis/glossary. html.

Committee for Mineral Reserves International Reporting Standards, 2006, International reporting template for the reporting of exploration results, mineral resources, and mineral reserves: Committee for Mineral Reserves International Reporting Standards, 53 p. (Also available at http://www.crirsco.com/crirsco_template_first_ ed_0806.pdf.)

Cox, D.L., and Singer, D.A., 1986, Mineral deposit models: U.S. Geological Survey Bulletin 1693, 379 p.
Cunningham, C.G., Zappettini, E.O., Vivallo S., Waldo, Celada, C.M., Quispe, Jorge, Singer, D.A., Briskey, J.A, Sutphin, D.M., Gajardo M., Mariano, Diaz, Alejandro, Portigliati, Carlos, Berger, V.I., Carrasco, Rodrigo, and Schulz, K.J., 2008, Quantitative mineral resource assessment of copper, molybdenum, gold, and silver in undiscovered porphyry copper deposits in the Andes Mountains of South America: U.S. Geological Survey Open-File Report 2008-1253, 282 p., available on CD-ROM and at http://pubs.usgs.gov/ of/2008/1253/.

Harris, D.P., 1984, Mineral resources appraisal: New York, Oxford University Press, Oxford, U.K. 445 p.

Long, K.R., DeYoung, J.H., and Ludington, S.L., 2000, Significant deposits of gold, silver, copper, lead, and zinc in the United States: Economic Geology, v. 95, no. 3, p. 629-644.

Singer, D.A., 1993, Basic concepts in three-part quantitative assessments of undiscovered mineral resources: Nonrenewable Resources, v. 2, no. 2, p. 69-81.

Singer, D.A., 1995, World class base and precious metal deposits-A quantitative analysis: Economic Geology, v. 90, no.1, p. 88-104.

Singer, D.A., and Berger, V.I., 2007, Deposit models and their application in mineral resource assessments, in Briskey, J.A., Schulz, K.J., eds., Proceedings for a workshop on deposit modeling, mineral resource assessment, and their role in sustainable development: U.S. Geological Survey Circular 1294, p. 71-78, (Also available at http://pubs.usgs.gov/ circ/2007/1294/.)

Singer, D.A., and Menzie, W.D., 2010, Quantitative mineral resource assessments_-An integrated approach: New York, Oxford University Press, 219 p.

Taylor, H.K., 1972, General background theory of cutoff grades: Transactions of the Institute of Mining and Metallurgy, v. 81, section A, p. A160-79.

U.S. Bureau of Mines and U.S. Geological Survey, 1976, Principles of a resource/reserve classification for minerals: U.S. Geological Survey Circular 831, 5 p.

U.S. Geological Survey National Oil and Gas Resource Assessment Team, 1995, 1995 National assessment of United States oil and gas resources, Overview of the 1995 national assessment of potential additions to technically recoverable resources of oil and gas-onshore and state waters of the United States: U.S. Geological Survey Circular 1118, 20 p.

U.S. Geological Survey National Mineral Resource Assessment Team, 2000, 1998 assessment of undiscovered deposits of gold, silver, copper, lead, and zinc in the United States: U.S. Geological Survey Circular 1178, 21 p. 
Menlo Park Publishing Service Center, California

Manuscript approved for publication, June 9, 2014

Edited by Sarah E. Nagorsen and Chet Zenone

Layout and design by Sharon L. Wahlstrom 
